\title{
Identification and quantification of organic aerosol from cooking and other sources in Barcelona using aerosol mass spectrometer data
}

\author{
C. Mohr ${ }^{1, *}$, P. F. DeCarlo ${ }^{1, * *}$, M. F. Heringa ${ }^{1}$, R. Chirico ${ }^{1,{ }^{* * *}}$, J. G. Slowik ${ }^{1}$, R. Richter ${ }^{1}$, C. Reche ${ }^{2}$, A. Alastuey ${ }^{2}$, \\ X. Querol $^{2}$, R. Seco ${ }^{3, * * *}$, J. Peñuelas ${ }^{3}$, J. L. Jiménez ${ }^{4,5}$, M. Crippa ${ }^{1}$, R. Zimmermann ${ }^{6,7}$, U. Baltensperger ${ }^{1}$, and \\ A. S. H. Prévôt ${ }^{1}$ \\ ${ }^{1}$ Laboratory of Atmospheric Chemistry, Paul Scherrer Institut (PSI), Villigen, Switzerland \\ ${ }^{2}$ Institute for Environmental Assessment and Water Research (IDAEA-CSIC), Barcelona, Spain \\ ${ }^{3}$ Unitat d'Ecologia Global CREAF-CEAB-CSIC, Centre de Recerca Ecològica i Aplicacions Forestals, Universitat Autònoma \\ de Barcelona, Barcelona, Spain \\ ${ }^{4}$ Department of Chemistry and Biochemistry, University of Colorado, Boulder, USA \\ ${ }^{5}$ Cooperative Institute for Research in the Environmental Sciences (CIRES), University of Colorado, Boulder, USA \\ ${ }^{6}$ Helmholtz Zentrum Munchen, Joint Mass Spectrometry Center, Institute of Ecological Chemistry, Neuherberg, Germany \\ ${ }^{7}$ Analytical Chemistry, Institute of Chemistry, University of Rostock, Rostock, Germany \\ * now at: Department of Atmospheric Sciences, University of Washington, Seattle, USA \\ *** now at: Department of Civil, Architectural, and Environmental Engineering, Drexel University, Philadelphia, USA

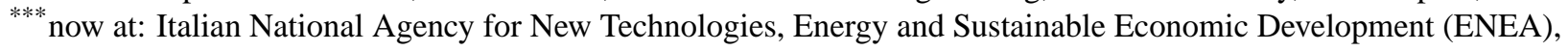 \\ UTAPRAD-DIM, Frascati, Italy \\ ${ }^{* * * *}{ }_{n}$ now at: Atmospheric Chemistry Division, National Center for Atmospheric Research, Boulder, USA
}

Correspondence to: A. S. H. Prévôt (andre.prevot@psi.ch)

Received: 18 September 2011 - Published in Atmos. Chem. Phys. Discuss.: 6 October 2011

Revised: 18 January 2012 - Accepted: 1 February 2012 - Published: 15 February 2012

\begin{abstract}
PM}_{1}$ (particulate matter with an aerodynamic diameter $<1 \mu \mathrm{m})$ non-refractory components and black carbon were measured continuously together with additional air quality and atmospheric parameters at an urban background site in Barcelona, Spain, during March 2009 (campaign DAURE, Determination of the sources of atmospheric Aerosols in Urban and Rural Environments in the western Mediterranean). Positive matrix factorization (PMF) was conducted on the organic aerosol (OA) data matrix measured by an aerosol mass spectrometer, on both unit mass (UMR) and high resolution (HR) data. Five factors or sources could be identified: LV-OOA (low-volatility oxygenated OA), related to regional, aged secondary OA; SVOOA (semi-volatile oxygenated OA), a fresher oxygenated OA; HOA (hydrocarbon-like OA, related to traffic emissions); BBOA (biomass burning OA) from domestic heating or agricultural biomass burning activities; and COA (cooking OA). LV-OOA contributed $28 \%$ to OA, SV-OOA $27 \%$, COA $17 \%$, HOA $16 \%$, and BBOA $11 \%$. The COA HR spectrum contained substantial signal from oxygenated ions (O:C: 0.21 ) whereas the HR HOA spectrum had almost ex-
\end{abstract}

clusively contributions from chemically reduced ions (O:C: 0.03 ). If we assume that the carbon in HOA is fossil while that in COA and BBOA is modern, primary OA in Barcelona contains a surprisingly high fraction (59\%) of non-fossil carbon.

This paper presents a method for estimating cooking organic aerosol in ambient datasets based on the fractions of organic mass fragments at $\mathrm{m} / \mathrm{z} 55$ and 57: their data points fall into a V-shape in a scatter plot, with strongly influenced HOA data aligned to the right arm and strongly influenced COA data points aligned to the left arm. HR data show that this differentiation is mainly driven by the oxygen-containing ions $\mathrm{C}_{3} \mathrm{H}_{3} \mathrm{O}^{+}$and $\mathrm{C}_{3} \mathrm{H}_{5} \mathrm{O}^{+}$, even though their contributions to $m / z 55$ and 57 are low compared to the reduced ions $\mathrm{C}_{4} \mathrm{H}_{7}^{+}$ and $\mathrm{C}_{4} \mathrm{H}_{9}^{+}$. A simple estimation method based on the markers $m / z 55,57$, and 44 is developed here and allows for a first-order-estimation of COA in urban air. This study emphasizes the importance of cooking activities for ambient air quality and confirms the importance of chemical composition measurements with a high mass and time resolution. 


\section{Introduction}

Atmospheric aerosols, liquid or solid particles suspended in air, are of interest due to their impact on climate (IPCC, 2007), visibility (Watson, 2002), ecosystems (Grantz et al., 2003), and human health (Nel, 2005). Numerous natural and anthropogenic sources directly emit particles into the air, or release gas-phase precursors whose oxidation products partition into the particle phase. Consequently, the chemical composition of ambient particulate matter (PM) varies considerably and consists of many different compounds (Tsigaridis et al., 2006). A major aerosol constituent is organic material (Murphy et al., 2006; Jimenez et al., 2009). However, knowledge about sources, fate and mutual interaction of gasphase and aerosol organics, of which it is estimated that there are between 10000 and 100000 different compounds, is still limited (Goldstein and Galbally, 2007). Therefore, the atmospheric evolution of organic aerosol (OA) is the focus of intense research activities (Jimenez et al., 2009).

The complexity of the atmospheric (organic) aerosol system places great demands on measurement techniques and instrumentation (Hallquist et al., 2009). Aerosol mass spectrometers (AMS) have become a widely applied tool (Baltensperger et al., 2010), because they allow chemical speciation, sizing and mass detection of submicron non-refractory PM at high time resolution (Canagaratna et al., 2007). Zhang et al. (2005a) deconvolved and quantified the mass concentrations of hydrocarbon-like OA (HOA, a surrogate for primary OA, POA) and oxygenated OA (OOA, a surrogate for secondary OA, SOA) using organic mass spectra obtained with an AMS. Recently, AMS data have been combined with positive matrix factorization (PMF, Paatero and Tapper, 1994; Lanz et al., 2007; Ulbrich et al., 2009), a factor analytical model which outputs a number of constant source profiles (factors) and their varying contributions over time. This has led to new insights into sources contributing to $\mathrm{OA}$ and made the quantification of OA subtypes such as low-volatility and semi-volatile OOA (LV- and SV-OOA), HOA, and biomass burning OA (BBOA) possible (Lanz et al., 2007; Jimenez et al., 2009). A growing number of measurements in very diverse environments (e.g. Aiken et al., 2009; Huang et al., 2010) and increasing resolution of the AMS (DeCarlo et al., 2006) continuously enhance our knowledge of OA factors.

An OA factor recently reported in ambient air in several AMS studies is cooking organic aerosol (COA, Allan et al., 2010; Huang et al., 2010; Sun et al., 2011). Emissions from cooking activities had been identified as a potentially important source of PM much earlier (Gray, 1986). To a great extent an indoor air pollution problem (Fortmann et al., 2001), cooking aerosol can also contribute substantially to ambient PM concentrations: e.g. meat charbroiling and frying were estimated to account for about $16 \%$ of fine organic carbon emissions or $6 \%$ of total fine PM concentration in the Los Angeles area (Hildemann et al., 1991a; Schauer et al., 1996). Most studies focused on meat cooking emissions when investigating cooking aerosol; numerous compounds were identified in meat cooking OA, among which palmitic acids, stearic acid, oleic acid, and cholesterol are the most prominent (Cass, 1998; Schauer et al., 1999). Charbroiling OA was also identified in ambient air by AMS-PMF analyses (Lanz et al., 2007; Slowik et al., 2010). Schauer et al. (2001) extended the research on cooking PM to emissions from cooking vegetables with seed oils; studies on Chinese food cooking emissions further broadened the range of emissions investigated (He et al., 2004, 2010; Zhao et al., 2006). Fatty acids are the dominant group of compounds emitted by all cooking types; they differ in fractions of saturated, unsaturated, and polyunsaturated fats depending on the type of oil or meat fat (Zhao et al., 2006). Mohr et al. (2009) characterized primary OA from cooking various types of meat with an AMS and found that the unit mass resolution (UMR) spectral signature is very similar to HOA. The differences in the high resolution (HR) spectra are larger due to the oxygen present in the fatty acids; however, the similarity of UMR spectra from HOA and COA might be one of the reasons for the relatively small number of locations where COA was detected with an AMS, despite its potential importance as a contributor to urban aerosol concentrations.

This paper provides a characterization of the chemical composition and organic aerosol sources of $\mathrm{PM}_{1}$ in Barcelona during winter. In addition, a new method for identifying COA in ambient air and estimating cooking contributions to organic aerosol is presented. These techniques are demonstrated within the framework of the DAURE (Determination of the sources of atmospheric Aerosols in Urban and Rural Environments in the western Mediterranean) campaign in Barcelona, Spain. The intense and varied sources of primary emissions in this region provide an ideal test case for the feasibility of identifying cooking emissions and determining their importance relative to other OA sources.

\section{Method}

\subsection{DAURE Campaign, Barcelona (Spain)}

Data for this study were acquired during the intensive field campaign DAURE in Barcelona, Spain, from 25 February to 26 March 2009. The DAURE campaign was set up to study the aerosol formation processes during the winter anticyclonic episodes, when the highest $\mathrm{PM}_{1}$ levels are recorded both at urban and regional scale in the Western Mediterranean (Pey et al., 2010). Thus, the aerosol sampled during this period is characterized by higher ambient concentrations, especially of nitrate and carbonaceous components, when compared with the urban background mean annual average in Barcelona (Pérez et al., 2008b). A detailed overview of the campaign, its objectives, the groups involved, the measurements performed, and a summary of the results are presented in Pandolfi et al. (2012). 
The city of Barcelona is situated on the shore of the western Mediterranean basin, wedged in between the sea and the Catalan coastal ranges running parallel to the coastline NESW. The Besos and the Llobregat river valleys perpendicular to the coast limit the city area to the NE and SW. The warm and dry Mediterranean climate, intense solar radiation and low dispersive conditions favor high levels of regional aerosol (Pérez et al., 2008a); additionally, high anthropogenic emissions lead to intense pollution episodes. Barcelona is one of the cities in Europe with the highest number of cars per $\mathrm{km}^{2}$ (Ajuntament de Barcelona, 2007). Emissions from the Barcelona harbor, an expanded industrial zone in the river valley and the densely populated pre-coastal depression behind the coastal range all add additional PM to the Barcelona area aerosol concentrations (Querol et al., 2001). Outbreaks of Saharan dust events can affect the Barcelona air quality (Pérez et al., 2006). The daily cycle of nocturnal offshore flows and diurnal sea breeze (Jorba et al., 2011) plays an important role for the pollution dispersion in Barcelona. The sea breeze advects (polluted) coastal air masses inland, while nocturnal land breeze and mountain down slope flows transport air masses from the surrounding valleys to the city of Barcelona.

The measurement site was situated at the northwestern corner of the city centre in a small park (elevation $80 \mathrm{~m}$ a.s.l.) surrounded by residential areas. At a distance of $\sim 300 \mathrm{~m}$ is Diagonal Avenue, one of the main traffic arteries crossing Barcelona with 100000 vehicles per day (Ajuntament de Barcelona, 2007), while the Mediterranean sea is $\sim 6 \mathrm{~km}$ away.

\subsection{Instrumentation and sampling}

A complete list of instruments deployed during DAURE is given in Pandolfi et al. (2012). A brief discussion of the instruments used for the present analysis is included here. Nonrefractory $\mathrm{PM}_{1}$ chemical composition was measured with an Aerodyne high-resolution time-of-flight aerosol mass spectrometer (HR-ToF-AMS). This version of the AMS allows the distinction of different ions at the same nominal mass-tocharge ratio $(\mathrm{m} / \mathrm{z})$. It can be run in two ion optical modes, a single reflection mode with higher sensitivity and lower resolving power referred to as V-mode, and a so-called W mode with a two-reflectron configuration that yields higher resolving power but lower sensitivity. A detailed description of the instrument can be found in DeCarlo et al. (2006). During DAURE the HR-ToF-AMS (abbreviated as AMS hereafter) was operated alternately in $\mathrm{V}$ and $\mathrm{W}$ mode $(150 \mathrm{~s}$ each). In $\mathrm{W}$ mode, 15 cycles of $5 \mathrm{~s}$ open and $5 \mathrm{~s}$ closed data in the mass spectrum (MS) mode were acquired before saving. In $\mathrm{V}$ mode, 5 cycles of $15 \mathrm{~s}$ in MS mode (50\% open) plus $30 \mathrm{~s}$ in particle time-of-flight (PToF) mode yielded the size distribution of $\mathrm{PM}_{1}$ components.

A scanning mobility particle sizer (SMPS, homebuilt by PSI, consisting of a neutralizer with a ${ }^{85} \mathrm{Kr}$ source, a differ- ential mobility analyzer DMA, and a condensation particle counter CPC 3022A, TSI) was operated in parallel to the AMS. It measured submicron particle number size distributions between 13 and $638 \mathrm{~nm}$ mobility diameter with a time resolution of $5 \mathrm{~min}$.

Aerosol black carbon (BC) mass concentrations were derived from particle light attenuation $\left(b_{\mathrm{ATN}}\right)$ measurements (time resolution $5 \mathrm{~min}$ ) at a wavelength of $880 \mathrm{~nm}$ by an aethalometer, Model AE31 (Magee Scientific).

An optical counter (Grimm Labortechnik GmbH \& Co. KG; model 1.107) provided continuous measurements of $\mathrm{PM}_{1}$ (and $\mathrm{PM}_{2.5}$ and $\mathrm{PM}_{10}$, not shown) with a time resolution of $1 \mathrm{~h}$. The Grimm mass loadings were corrected using $\mathrm{PM}_{1}$ samples collected on filters as discussed by Reche et al. (2011), using the following parameters: Grimm $\mathrm{PM}_{1}=\left(\mathrm{PM}_{1}\right.$ [uncorrected] $\left.-(-0.0024)\right) / 0.8236$.

The above instruments were deployed on a common sample inlet with a $\mathrm{PM}_{2.5}$ cyclone (SCC 1.829 , BGI Incorporated), requiring a flow rate of $51 \mathrm{~min}^{-1}$. The inlet was situated on the roof of the trailer containing the instruments, at a height of $\sim 4 \mathrm{~m}$ above ground. A $1 / 2$ inch outer diameter (o.d.) stainless steel tube led inside the trailer (length $2.3 \mathrm{~m}$ ) to a manifold. From there the sample air flowed (flow rate 0.4 $1 \mathrm{~min}^{-1}$ ) through a Nafion dryer (Perma-Pure, length $100 \mathrm{~cm}$ ) and $40 \mathrm{~cm}$ of $1 / 4$ inch o.d. stainless steel tube to the inlet of the AMS. The SMPS inlet was connected to the Nafion dryer with a $120 \mathrm{~cm}$ long copper tube, $6 \mathrm{~mm}$ o.d. Copper tubing with $105 \mathrm{~cm}$ of $6 \mathrm{~mm}$ o.d. and $10 \mathrm{~cm}$ of $10 \mathrm{~mm}$ o.d. led to the aethalometer. The total inlet residence time was $14 \mathrm{~s}$ for the AMS and $10 \mathrm{~s}$ for the SMPS under laminar flow, and $3.5 \mathrm{~s}$ for the aethalometer, whose last part of the inlet flow was slightly turbulent (Reynolds Number $R e=2160$ ).

\subsection{Data analysis}

AMS data were analyzed using the standard AMS data analysis software SQUIRREL v1.51B and PIKA v1.10B (Sueper, 2008) within Igor Pro 6.22A (Wavemetrics). A collection efficiency (CE) dependent on the nitrate fraction $f_{\mathrm{NO}_{3}}$ was applied to the entire dataset, with $\mathrm{CE}=0.5$ for $f_{\mathrm{NO}} \leq 0.25$, $\mathrm{CE}=1$ for $f_{\mathrm{NO}_{3}} \geq 0.78$ and a linear increase of CE between these values for $0.25 \leq f_{\mathrm{NO}_{3}} \leq 0.78$. This relationship was empirically determined by comparisons of AMS and ancillary data from various field campaigns conducted within the European integrated project on aerosol cloud climate air quality interactions (EUCAARI) and the European monitoring and evaluation programme (EMEP) all over Europe (Nemitz et al., 2011). DAURE data were included in that collection of data sets. A very similar dependence of CE on $f_{\mathrm{NO}_{3}}$ was recently reported by Middlebrook et al. (2012) for studies in the US. The time series of the estimated CE can be found in Fig. S1.

Positive matrix factorization (PMF, Paatero and Tapper, 1994; Lanz et al., 2007) was applied to both unit mass resolution (UMR) and high resolution (HR) organic spectra 


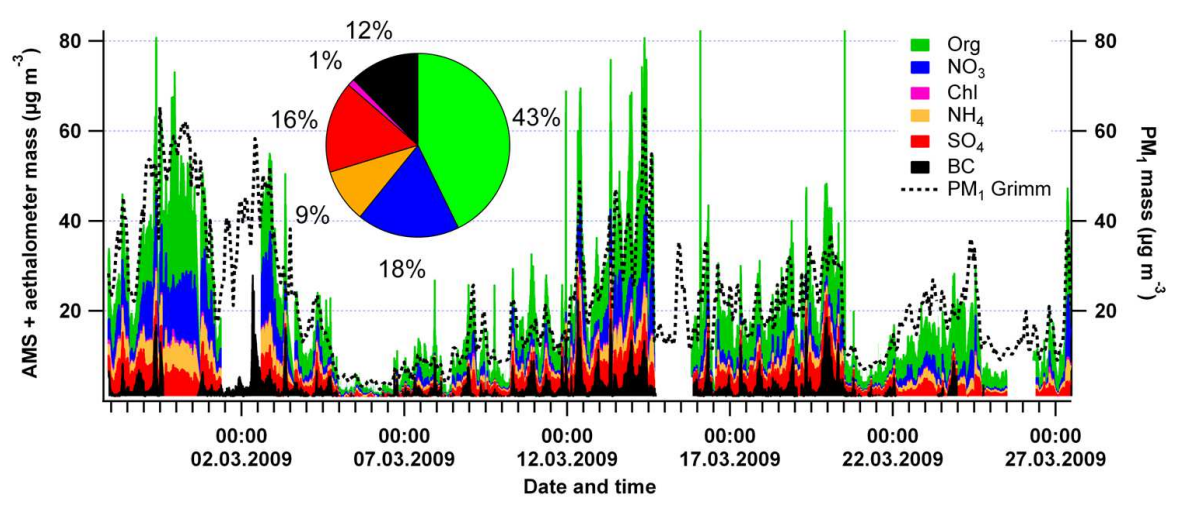

Fig. 1. Stacked time series of $\mathrm{AMS}$ species (Org, $\mathrm{NO}_{3}, \mathrm{NH}_{4}, \mathrm{SO}_{4}$, and $\left.\mathrm{Chl}\right), \mathrm{BC}$ measured by the aethalometer. $\mathrm{PM}_{1}$ data from the Grimm laser-spectrometer (corrected using $\mathrm{PM}_{1}$ samples collected on filters) are plotted on the right axis. The pie chart shows the campaign averagerelative contributions of AMS species and BC to PM1 (campaign average concentration: $18.5 \mu \mathrm{g} \mathrm{m}^{-3}$ ).

measured by AMS to investigate factors or sources contributing to the organic mass loadings. The UMR input matrices were prepared according to the protocol outlined in U1brich et al. (2009) and comprised $m / z$ 's 12-300. The HR data and error matrices were generated as outlined in DeCarlo et al. (2010). Ions from $m / z$ 's 12-115 were included in the data matrix; isotopes whose signal was constrained as the appropriate fraction of the peak area of their parent ion were removed. Elemental analysis of the HR data and PMF factors was done using the software APES v1.05 (Sueper, 2008) within Igor Pro 6.22A. SMPS data were analyzed and corrected for multiply charged particles using the PSI inversion routine (Wiedensohler et al., 2011).

$b_{\text {ATN }}$ measured at $880 \mathrm{~nm}$ by the aethalometer was corrected for multiple scattering of the light beam within the unloaded filter matrix $(C=2.81$, Collaud Coen et al., 2010) and for the "shadowing" caused by the deposited particles $(f=1.2)$ following the procedure by Weingartner et al. (2003), yielding the aerosol absorption coefficient $b_{\text {abs. }} . b_{\text {abs }}$ and an absorption cross-section $\sigma_{\text {abs }}=\sigma_{\text {ATN }} / C$ of $5.91 \mathrm{~m}^{2} \mathrm{~g}^{-1}\left(\sigma_{\text {ATN }}=16.6 \mathrm{~m}^{2} \mathrm{~g}^{-1}\right.$ delivered by the aethalometer data software) were then used to calculate $\mathrm{BC}$ mass concentration at $880 \mathrm{~nm}$. All data are reported at local pressure and temperature conditions in local standard time (UTC + 1).

\section{Results}

\section{1 $\mathrm{PM}_{1}$ time series and bulk chemical composition}

Figure 1 shows the time series of the cumulative mass of organics $(\mathrm{Org})$, nitrate $\left(\mathrm{NO}_{3}\right)$, chloride $(\mathrm{Chl})$, ammonium $\left(\mathrm{NH}_{4}\right)$, sulfate $\left(\mathrm{SO}_{4}\right)$, and $\mathrm{BC}$ for the duration of the DAURE campaign. Charges are omitted for AMS nominally inorganic species, because non-ionic organosulfates and organonitrates may also contribute to their concentra- tions (Farmer et al., 2010). The beginning of the campaign (25 February 2009-4 March 2009) and the second part (8-25 March 2009) were influenced by typical winter anti-cyclonic conditions in the Western Mediterranean Basin (WMB) which favor the accumulation of pollutants within the planetary boundary layer (PBL). Peak $\mathrm{PM}_{1}$ concentrations of more than $60 \mu \mathrm{g} \mathrm{m}^{-3}$ were measured. The land/sea breeze cycle strongly influenced the daily evolution of pollutant concentrations during these episodes. The period from 4-8 March 2009 was characterized by Atlantic advection, with strong winds and precipitation on 5 March 2009. Clean air masses coming from the Atlantic renewed the polluted PBL and lowered concentrations $\left(5-15 \mu \mathrm{g} \mathrm{m}^{-3}\right.$ of $\mathrm{PM}_{1}$ ). The meteorological diurnal cycle was less distinct. Further details on meteorological and dispersion conditions during DAURE can be found in Jorba et al. (2011) and Pandolfi et al. (2012). Since the SMPS was used to estimate the AMS CE, Grimm $\mathrm{PM}_{1}$ data were added for comparison purposes. The campaign average concentration value of $18.5 \mu \mathrm{g} \mathrm{m}^{-3}$ of $\mathrm{PM}_{1}$ compares well to $20 \mu \mathrm{g} \mathrm{m}^{-3}$ of $\mathrm{PM}_{1}$ measured by combined AMS and aethalometer data. The coefficients of a least orthogonal distance fit shown in Fig. S2 (intercept $=-3.60$, slope $=0.99$ ) confirm the good agreement of AMS plus aethalometer vs. Grimm data.

The campaign average dry chemical composition of $\mathrm{PM}_{1}$ is shown in the pie chart inset in Fig. 1. The organic fraction makes up the largest part with $43 \%$, followed by nitrate $(18 \%)$, sulfate $(16 \%)$, BC $(12 \%)$, and ammonium $(9 \%)$. Molar ratios of the inorganic species indicate a neutralized aerosol throughout the campaign and low mass fractions of organosulfate and organonitrates compared to the inorganic forms, consistent with results at other locations (Docherty et al., 2011). Similar results were found by Pandolfi et al. (2012) using 12 -h chemically speciated filter data $\left(\mathrm{PM}_{1}\right)$ : Excluding the crustal, marine and unidentified fractions from the filter data, organic matter (OM) accounts for $40 \%, \mathrm{NO}_{3}^{-}$ 
for $15 \%, \mathrm{NH}_{4}^{+}$and $\mathrm{SO}_{4}^{2-}$ for $16 \%$ each, and elemental carbon (EC) makes up $14 \%$. Comparisons of AMS nitrate to $\mathrm{PM}_{2.5}$ nitrate measured by an $\mathrm{R} \& \mathrm{P}$ ambient particulate nitrate monitor (8400N, Rupprecht and Patashnick Co., Inc.) show good agreement $\left(R^{2}=0.92\right)$, with the $\mathrm{PM}_{2.5}$ nitrate being $30 \%$ higher.

\subsection{PMF: identification of sources/components of organic aerosol (OA)}

\subsubsection{Factor profiles and time series}

For both the UMR and HR organic data matrix, 5 factors could be identified using PMF: low-volatility and semivolatile oxygenated OA (LV-OOA and SV-OOA, the latter is a recombination of two individual factors, see section below), hydrocarbon-like OA (HOA), biomass burning OA (BBOA), and cooking OA (COA). Since the HR data matrix provides an increased level of information (individual ion signal) compared to the UMR data, factor profiles, time series, and main conclusions are based on the HR PMF solution. However, as there are versions of the AMS that only provide UMR data (aerosol chemical speciation monitor ACSM, Ng et al., 2011b; C-ToF-AMS, Drewnick et al., 2005; quadrupoleAMS, Canagaratna et al., 2007), the UMR PMF solution and a comparison of the UMR and HR PMF solution are presented in the SI, Sects. 3.1 and 3.2. For a discussion of the number of factors chosen and the criteria used to select the best UMR solution, we again refer the reader to the SI, Sect. 3.3. HR solution criteria are briefly outlined here, figures can be found in the SI, Sect. 3.4.

The chosen 6-factor solution for the HR dataset is presented in Fig. S15. The two SV-OOA factors were recombined into a single SV-OOA factor using the sum of the time series and the loadings-weighted average of the spectra. The 5-factor solution (Fig. S16) was discarded due to the high similarity of two factors (spectra and time series). The 7factor solution (Fig. S17) features three LV-OOA spectra: PMF seems to assign an individual LV-OOA factor to three different sections in the time series, which can be due to small variations in instrument tuning with time. As the variation in the solution space $p=6$ as a function of $f$ peak, a user-specified rotational parameter, is negligible (Figs. S18$19)$, the most central solution $(f$ peak $=0)$ was chosen and different SEED values (random initial values) were explored (Figs. S20 - 21). SEED $=46$ was chosen as the best solution due to correlations with reference spectra, even though it exhibits the highest $Q / Q_{\text {expected value (12.75 compared to }}$ $\sim 12.55$ for SEED $\neq 46$ ) and is thus not the mathematically optimal solution (see SI 3.3). A boxplot of the scaled residuals (boxes are $\pm 25 \%$ of points) per $m / z$ is shown in Fig. S22, time series of the residuals and $Q / Q_{\text {expected }}$ are shown in Fig. S23. $Q / Q_{\text {expected }} \gg 1$ (12.75) indicates an underestimation of the number of factors or of the errors in the input data, possibly due to fitting errors in the HR data which are cur- rently not included in the total error estimation. In addition to $p>6$ (which was explored and shown not to give a more plausible solution, see above), the introduction of a "model error term" might also reduce $Q / Q_{\text {expected }}$, however, as discussed in Ulbrich et al. (2009), this is usually not applied in AMS data sets. $Q / Q_{\text {expected }}$ values $\gg 1$ for HR-ToF-AMS data have been shown recently by other authors, e.g. Allan et

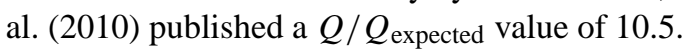

Figure 2 shows the HR mass spectra of the 5 resulting factors. OOA is generally dominated by secondary organic aerosol formed in the atmosphere from gas-to-particle conversion processes of the oxidation products of volatile organic compounds (VOCs, Hallquist et al., 2009). Numerous sources emitting a large number of different organic species (Goldstein and Galbally, 2007) contribute to OOA formation. However, photochemical aging causes the OOA UMR spectra to become progressively more and more similar and lose their source fingerprint (Andreae, 2009; Capes et al., 2008). Simultaneously, the fraction of $\mathrm{m} / \mathrm{z} 44\left(\mathrm{CO}_{2}^{+}\right)$, mostly from the decarboxylation of carboxylic acids, increases ( $\mathrm{Ng}$ et al., 2010). We use the terms "LV-OOA" and "SV-OOA" as introduced by Jimenez et al. (2009) although we did not explicitly measure the volatility of the compounds within this study. LV-OOA and SV-OOA factors serve as a basis set for describing the range of physicochemical properties occurring in the dynamic evolution of OOA (Jimenez et al., 2009). The LV-OOA spectrum found here features dominant signals at $m / z, 44$ (with the signal at $\mathrm{m} / \mathrm{z}, 28$ assumed equal to $\mathrm{m} / \mathrm{z} 44$, Aiken et al., 2008). The $R^{2}$ of its correlation with the standard UMR LV-OOA spectrum from $\mathrm{Ng}$ et al. (2011a) is 0.96 (Uncentered $R=0.77$ ). The dominant ion families are $\mathrm{C}_{\mathrm{x}} \mathrm{H}_{\mathrm{y}} \mathrm{O}$ and $\mathrm{C}_{\mathrm{x}} \mathrm{H}_{\mathrm{y}} \mathrm{O}_{\mathrm{z}}(z>1)$; the $\mathrm{O}: \mathrm{C}$ atomic ratio of 0.75 confirms the high degree of oxygenation. This value lies in the middle of the LV-OOA O:C range spanned by the 2-D framework of OA aging (where the oxidation state approximated by the $\mathrm{O}: \mathrm{C}$ ratio is plotted against the saturation vapor pressure, Jimenez et al., 2009). It is in between the O:C ratios of 0.6 of the OOA spectrum found for Mexico City (where no separation of LV-OOA and SV-OOA was possible, Aiken et al., 2009) and 1.02 found for LV-OOA in aircraft measurements in the Mexico city region (DeCarlo et al., 2010). As also found by e.g. Lanz et al. (2007) and DeCarlo et al. (2010), the LV-OOA time series correlates with that of non-volatile, regionally-transported $\mathrm{SO}_{4}$ (see Fig. 3, $R^{2}=0.43$ for HR). Taken together with the high O:C ratio, this confirms LV-OOA as characteristic of aged, regional aerosol.

Investigation of the PMF factors' diurnal patterns helps greatly in their identification. Apart from varying emission sources and strengths during the course of a day, temperature-driven phenomena such as the sea breeze circulation and boundary layer heights play a very important role for the diurnal evolution of OA components. Figure 4 presents the median hourly concentration and the range spanned by the 1 st and the 3 rd quartile (shaded area). 
Consistent with its regional character, LV-OOA does not display a pronounced diurnal pattern.

The SV-OOA spectrum was calculated by recombining two individual factors found by PMF, as described in the Supplement. Correlation with the standard SV-OOA mass spectrum from $\mathrm{Ng}$ et al. (2011a) yields an $R^{2}$ of 0.86 (Uncentered $R=0.85$ ). High signal at $m / z, 44$ (and $m / z$ 28) identifies it as OOA; the O:C (0.32) ratio is lower than for LV-OOA due to substantial contributions from the non-oxygen-containing ions at e.g. $m / z, 29,43$, and 55. The substantial signal at the ion series $\mathrm{C}_{n} \mathrm{H}_{2 n+1}^{+}(\mathrm{m} / z 29,43,57,71$,$) and \mathrm{C}_{\mathrm{n}} \mathrm{H}_{2 \mathrm{n}-1}^{+}(\mathrm{m} / \mathrm{z}$ $41,55,69$,) from saturated alkanes, alkenes, and cycloalkanes, and the diurnal cycle exhibiting the typical rush-hour peaks around 09:00 and 22:00 local time (further increased later due to the increase in boundary layer height) indicate an influence from vehicle emissions. The highest concentrations are measured around 11:00, linked to rapid SOA formation from primary emissions (Reche et al., 2011). A small peak in the late afternoon, when the photochemical activity is very high, corresponds to the daily maximum of $\mathrm{O}_{3}$ concentrations (Pandolfi et al., 2012). The time series of SV-OOA shows a similar trend as the time series of the semi-volatile nitrate (see Fig. $3, R^{2}=0.22$ ) also seen in other locations (Lanz et al., 2007; DeCarlo et al., 2010); the diurnal patterns of both SV-OOA and $\mathrm{NO}_{3}$ (not shown) indicate that the temporal evolution of both components is driven by similar processes such as primary emissions, rapid chemical formation, and the diurnal cycles of land/sea breeze and boundary layer height rather than gas-to-particle partitioning based on volatility characteristics. SV-OOA can thus be described as of more local origin, less processed than LV-OOA.

The HOA factor is related to fossil fuel combustion. Diesel exhaust is typically dominated by recondensed engine lubricating oil and consists mainly of n-alkanes, branched alkanes, cycloalkanes, and aromatics (Canagaratna et al., 2004; Chirico et al., 2010), leading to high signal at the ion series $\mathrm{C}_{n} \mathrm{H}_{2 n+1}^{+}$and $\mathrm{C}_{\mathrm{n}} \mathrm{H}_{2 \mathrm{n}-1}^{+}$. Especially $m / z 57$ is a major mass fragment and often used as a tracer for HOA (Zhang et al., 2005a). Given the high number of diesel cars in Barcelona ( $>45 \%$ of the vehicle fleet, Reche et al., 2011) and proximity to the harbor, both vehicle and ship traffic could contribute to HOA (Murphy et al., 2009). However, the two distinct peaks in the morning and evening hours of the HOA diurnal cycle (Fig. 4) suggest road traffic emissions as the main source; the sea breeze during the afternoon hours and the increase in boundary layer height have a diluting effect on the primary emissions. $\mathrm{BC}$, particle number, toluene, benzene, and $\mathrm{NO}_{\mathrm{x}}$ peak at the same time of the day (Pandolfi et al., 2012). Correlation of the HOA factor found here with the standard HOA mass spectral profile from $\mathrm{Ng}$ et al. (2011a) yields an $R^{2}$ value of 0.94 (Uncentered $R=0.98$ ). Consistent with the dominance of the reduced hydrocarbon ions $\left(\mathrm{C}_{\mathrm{x}} \mathrm{H}_{\mathrm{y}}\right)$, the O:C ratio is very low (0.03), comparable to Mexico City (0.06, DeCarlo et al., 2010). The H:C elemental ratio (1.96) is the highest among the PMF factors. The HOA time se- ries (Fig. 3) correlates with benzene (measured by a proton transfer reaction-mass spectrometer PTR-MS, Ionicon Analytik), a natural constituent of gasoline and also formed by combustion $\left(R^{2}=0.66\right)$, supporting the identification of road traffic as a major HOA source. The fraction of black carbon from traffic emissions was approximated by calculating $b_{\mathrm{abs}}$ at $880 \mathrm{~nm}$ of PM from vehicle exhaust $\left(b_{\mathrm{abs}}(880 \mathrm{~nm})_{\text {traffic }}\right)$ using the model developed by Sandradewi et al. (2008), with an Angstrom exponent $\alpha_{\text {traffic }}=0.9$ (Herich et al., 2011). The model uses the Lambert-Beer law to obtain equations which relate the absorption coefficients $\left(b_{\text {abs }}\right)$ measured at two different wavelengths with the Angstrom exponents for conditions of pure traffic and pure biomass burning. The time series $b_{\text {abs }}(880 \mathrm{~nm})_{\text {traffic }}$ and the HOA time series show a similar trend. However, there are spikes in the HOA time series not caught by the aethalometer model. This can be due to a lower time resolution of the aethalometer compared to the AMS or peaks in the organics time series assigned to HOA without or with lower concurrent $\mathrm{BC}$ emissions (i.e. possible variations in $\mathrm{HOA} / \mathrm{BC}$ emission ratios of various vehicles or other fossil sources in the area). Removing 18 data points (out of 6329) from spikes in the HOA time series (see Fig. S24) increases the $R^{2}$ value from initially 0.17 to 0.52 .

BBOA in the Barcelona region can be emitted by regional agricultural open fires or due to long-range transported pollutants from forest or agricultural fires, and possibly also from wood-combustion heating systems in suburban and rural areas (Reche et al., 2012). Characteristic mass fragments of BBOA spectra are $\mathrm{m} / \mathrm{z} 60$ and 73 , attributed to $\mathrm{C}_{2} \mathrm{H}_{4} \mathrm{O}_{2}^{+}$ and $\mathrm{C}_{3} \mathrm{H}_{5} \mathrm{O}_{2}^{+}$, respectively. The ions are fragments of anhydrosugars such as levoglucosan, which are produced during cellulose pyrolysis (Alfarra et al., 2007). The BBOA time series closely follows the time series of the organic mass fragment 60 (Fig. 3). Contributions from $\mathrm{m} / \mathrm{z}, 29,43$, and 44 exceed the signals at $m / z, 60$ and 73 - however, as they are abundant in almost all PMF spectra, they cannot be used as tracer mass fragments for BBOA (Alfarra et al., 2007). Comparison of the BBOA factor found here with the standard BBOA spectrum from $\mathrm{Ng}$ et al. (2011a) yields an $R^{2}$ value of 0.8 (Uncentered $R=0.9$ ). BBOA contains high contributions from the oxygen-containing ion families. The O:C ratio of 0.24 is also higher than for the other primary sources, in accordance with findings by e.g. Alfarra et al. (2007) and Aiken et al. (2009). The time series of BBOA shows a similar trend as the $b_{\mathrm{abs}}(880 \mathrm{~nm})$ from wood burning $\left(b_{\mathrm{abs}}(880 \mathrm{~nm})_{\mathrm{wb}}\right)$, a surrogate for the BC fraction from biomass burning determined with the same method as $b_{\text {abs }}\left(880 \mathrm{~nm}\right.$ ) traffic and using $\alpha_{\mathrm{wb}}=1.9$ (Herich et al., 2011; Sandradewi et al., 2008). As the BBOA time series exhibits less spiky data than the HOA time series, the $R^{2}$ value $(0.31)$ is higher than for $b_{\text {abs }}(880 \mathrm{~nm})_{\text {traffic }}$ and HOA without removing the spikes from the fit. The low contribution of wood burning to BC measured in Barcelona ( $\sim 10 \%$ according to the aethalometer model) and related to that the uncertainties 


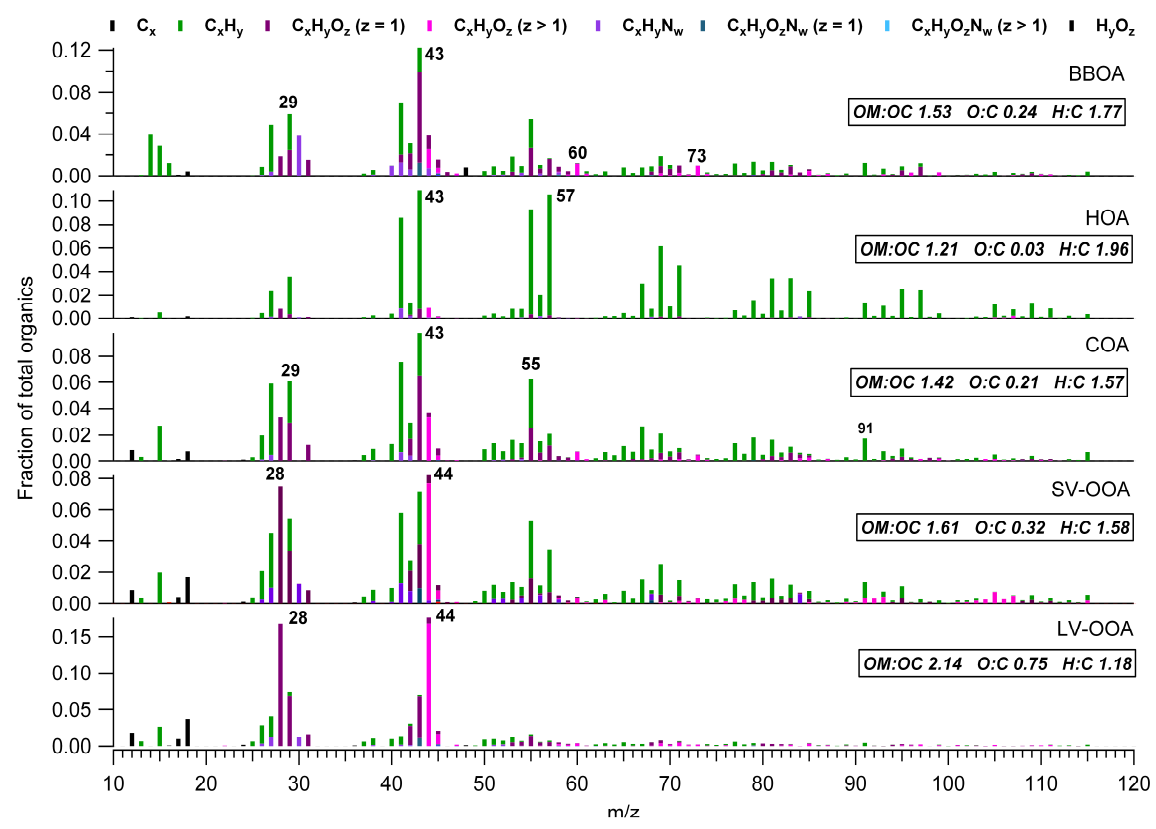

Fig. 2. Mass spectra of the 5-factor-PMF solution. The elemental ratios of the different factors are shown in boxes.

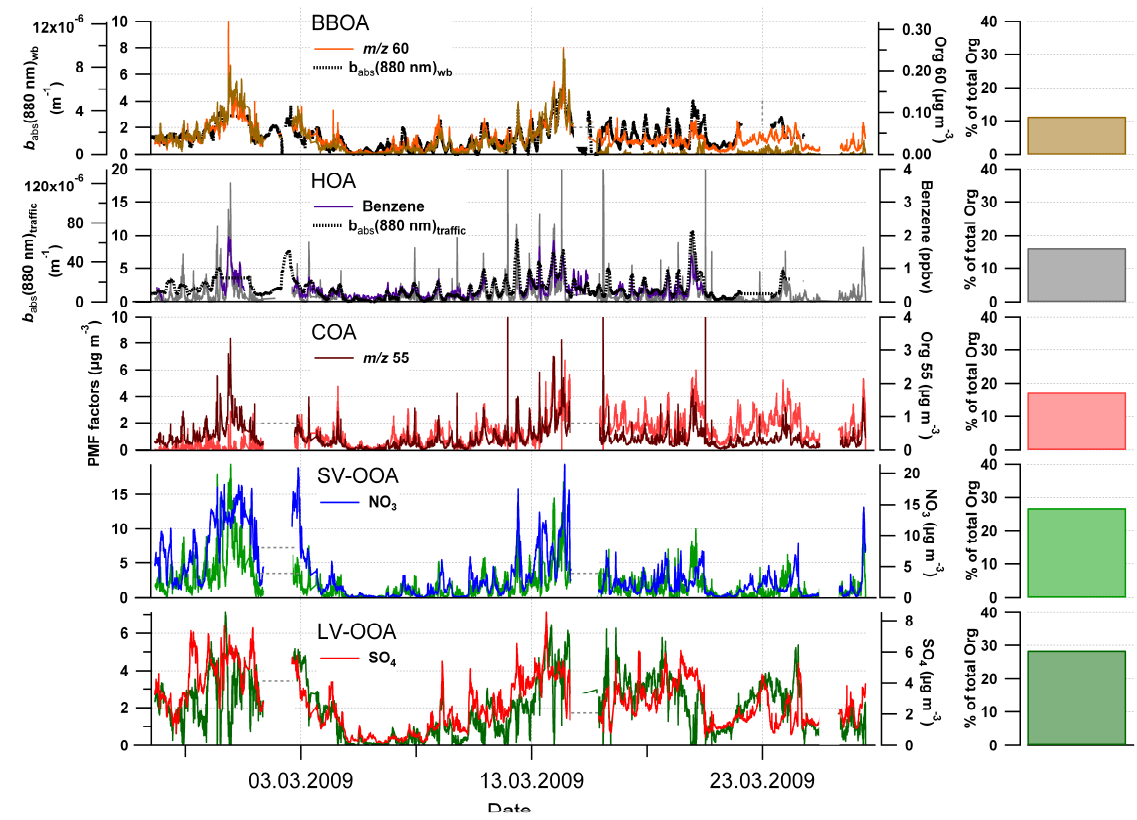

Fig. 3. Time series of the 5-factor-PMF solution and ancillary data. The right panels show the relative contributions of the respective factors to OA.

of $\left(b_{\mathrm{abs}}(880 \mathrm{~nm})_{\mathrm{wb}}\right)$ as a function of $\alpha_{\mathrm{wb}}$ probably lead to the weak correlation. BBOA exhibits a much smoother diurnal cycle than the other primary sources with no big peaks, which suggests that its sources are mainly outside of the city. As observed by Reche et al. (2012), concentrations during the night are slightly elevated due to smoke from open agri- cultural burning and heating systems in the surrounding valleys brought into the city by the land and downslope breezes.

COA has recently been identified as a major contributor to OA in several environments (Allan et al., 2010; Huang et al., 2010; Crippa et al., 2012). The COA spectrum exhibits signal from the same hydrocarbon ion series as the 


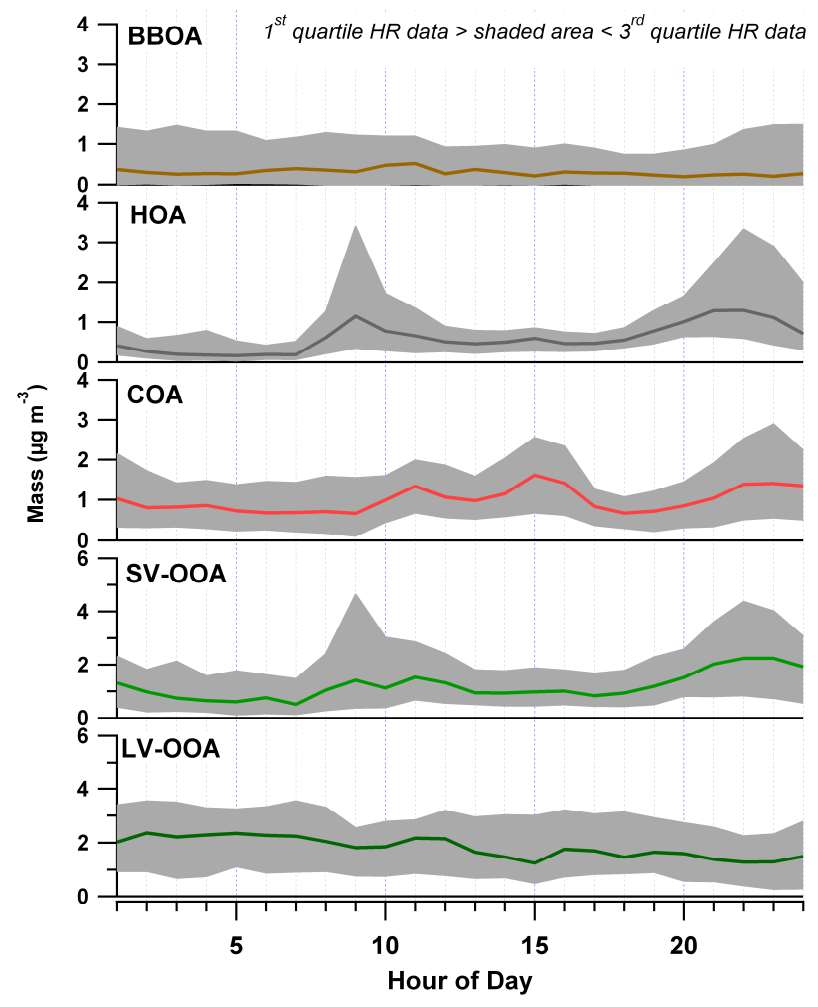

Fig. 4. Diurnal cycles of the 5-factor-PMF solution. The colored lines represent the median per hour of day, and the shaded area the range between the 1 st and the 3 rd quartile of the data.

HOA spectrum; however, the oxygen-containing ions substantially contribute to e.g. $\mathrm{m} / \mathrm{z}$ 's 43,55 , and 57 , consistent with the high degree of oxygenation of fatty acids, which are a major constituent of COA (Mohr et al., 2009; He et al., 2010). Consequently the elemental O:C ratio is higher (0.21) and the $\mathrm{H}: \mathrm{C}$ ratio lower (1.57) than for HOA. An important mass fragment of COA UMR spectra is $m / z 55$ (Lanz et al., 2007; Mohr et al., 2009; Allan et al., 2010; Sun et al., 2011). This is also shown by similarity of the time series of COA and the $m / z 55$ (Fig. 3). However, while the regression analysis of the UMR COA and $\mathrm{m} / z 55$ yields an $R^{2}$ of 0.59 , the $R^{2}$ of 0.13 for HR COA and $\mathrm{m} / z 55$ is too low to confirm correlation due to the varying ratios of HR COA to $m / z 55$. During the first part of the campaign (until 2 March 2009), HR COA is lower relative to $\mathrm{m} / \mathrm{z} 55$, after 15 March 2009 it is higher. Comparison of the COA factor found here with the COA factor from Manchester (Allan et al., 2010) results in an $R^{2}$ of 0.88 (Uncentered $R=0.93$ ). The diurnal cycle (Fig. 4) shows that COA concentrations already start to rise during the late morning hours and peak around 15:00 (shortly after Spanish lunch times), when the sea breeze is at a maximum and transports the COA from downtown to the measurement site, and later in the evening around 22:00, shortly after
Spanish dinner time, due to the lower nocturnal boundary layer height. The COA diurnal cycle is consistent with those reported in previous studies (Allan et al., 2010; Huang et al., 2010; Sun et al., 2011), with peaks during midday (depending on lunch times of the different countries) and in the later evening.

The right panel in Fig. 3 shows the mass of OA explained by the PMF factors. LV-OOA makes up $28 \%$ of the OA. SV-OOA contributes $27 \%$ to OA. Together, the secondary fraction accounts for $55 \%$ of OA. This dominance of OOA is consistent with previous findings for various locations in Northern hemisphere midlatitudes and in central Europe (Jimenez et al., 2009; Lanz et al., 2010). For the primary components, COA makes up $17 \%$, HOA $16 \%$, and BBOA $11 \%$.

The comparatively small fraction of HOA for Barcelona is surprising given its high traffic density. However, this finding is supported by Minguillón et al. (2011), who showed that for this specific winter period, $40 \%$ of the organic carbon (OC) of $\mathrm{PM}_{1}$ was fossil and $60 \%$ non-fossil. Considering the OM:OC ratios displayed in Fig. 2 of the three primarydominated components (BBOA, HOA, and COA), and assuming that all the carbon in HOA is fossil and all the carbon in BBOA and COA is non-fossil, we can estimate that $59 \%$ of the carbon in POA in Barcelona is non-fossil while $41 \%$ is fossil. The dominance of non-fossil carbon in urban POA is important for the interpretation of modern carbon measurements. Interestingly, the OM:OC ratios of the PMF spectra presented here and the results from Minguillón et al. (2011) also suggest a modern carbon fraction of $60 \%$ for all oxygenated OC (LV and SV). The COA fraction is roughly the same as HOA; cooking emissions, for which no control strategies have been implemented so far, appear to play a very important role for air quality under current conditions. Similar results were reported by Allan et al. (2010) and Crippa et al. (2012), who presented even higher COA fractions in two UK cities and Paris, respectively. The BBOA fraction found here (absolute mean value $0.8 \mu \mathrm{g} \mathrm{m}^{-3}$ for the whole campaign) is slightly lower than the biomass burning OM estimated from non-fossil EC and typical EC/OC ratios for biomass burning sources (Minguillón et al., 2011) or the Multilinear Engine (ME) receptor model applied on filter measurements (Reche et al., 2012) and slightly above the BBOA concentration determined by levoglucosan measurements (Minguillón et al., 2011). However, compared to the Mexico City region during the dry season when frequent forest fires contribute significantly to $\mathrm{PM}_{1}$ (mean value $2.5 \mu \mathrm{g} \mathrm{m}^{-3}$ for March 2006, Aiken et al., 2009) or Swiss Zurich winters when wood is burned for domestic heating purposes ( $\mathrm{PM}_{1}$ BBOA 2.4 and $3.5 \mu \mathrm{g} \mathrm{m}^{-3}$, Mohr et al., 2011; Lanz et al., 2008), biomass burning is a less important source of $\mathrm{OA}$ in Barcelona during winter time. 

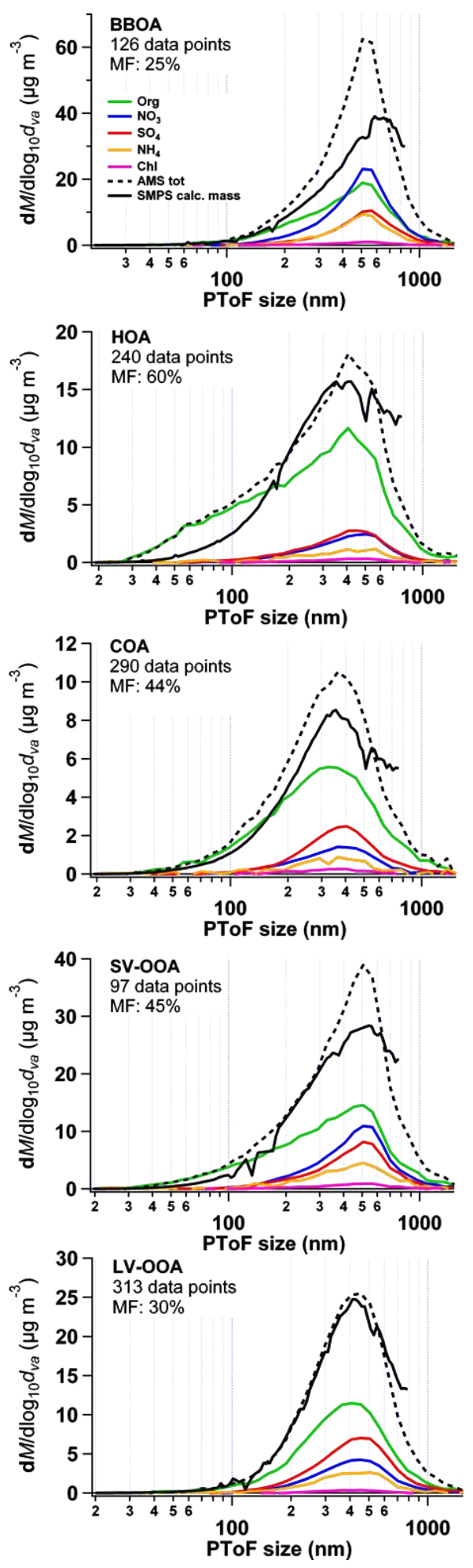

Fig. 5. Size distributions of $\mathrm{PM}_{1}$ components for periods with high LV-OOA, SV-OOA, COA, HOA or BBOA. The number of data points averaged and the organic mass fraction (MF) of the respective factor during those data points are given. Total AMS mass and SMPS data of the same time periods were added for comparison.

\subsubsection{Size distributions}

Figure 5 shows the mean mass size distributions of $\mathrm{PM}_{1}$ components for all periods when the percentage of total organics of either LV-OOA, SV-OOA, COA, HOA or BBOA was above its upper $95 \%$-percentile and, at the same time, all other PMF factors' fractions of total organics were below their upper $75 \%$-percentile. The number of points used in the average and the organic mass fractions of the corresponding factors during those periods are included in Fig. 5. Total AMS mass and SMPS data of the same time periods were added for comparison. The SMPS mass was calculated usingan average particle density based on the dry chemical compositiondetermined by the AMS (thus not including BC). The following densities $\rho\left(\mathrm{g} \mathrm{cm}^{-3}\right)$ were used (Duplissy et al., 2011): for Org, $\rho=1.27$; for $\mathrm{SO}_{4}, \rho=1.78$; for $\mathrm{NO}_{3}$, $\rho=1.72$; for $\mathrm{NH}_{4}, \rho=1.75$; and for Chl, $\rho=1.4$. The SMPS mobility diameter was converted to the vacuum aerodynamic diameter $\left(d_{\mathrm{va}}\right)$ (DeCarlo et al., 2004) using these densities and assuming spherical particles.

Periods with a larger impact of LV-OOA show a singlemode distribution peaking at $400 \mathrm{~nm} d_{\mathrm{va}}$ (accumulation mode), consistent with its identification as aged, regionally influenced aerosol (Zhang et al., 2005b). The total AMS and SMPS mass size distributions show very good agreement, indicating negligible concentrations of $\mathrm{BC}$ during high LV-OOA periods and sphericity of particles (DeCarlo et al., 2004; Slowik et al., 2004). During high SVOOA episodes, the size distribution exhibits both a strong accumulation mode and a smaller mode with $d_{\mathrm{va}}<100 \mathrm{~nm}$. This is most likely due to condensation of fresh secondary OA (Zhang et al., 2005b). Compared to the AMS total mass, the SMPS mass distribution is much broader with a lower accumulation mode peak height, indicating the potential role of non-spherical particles at higher sizes. Potential evaporative losses of semi-volatile species such as ammonium nitrate and SV-OOA in the DMA-CPC system (Gysel et al., 2007) could also lead to this underestimation (the ammonium nitrate fraction is larger during SV-OOA dominated periods than when LV-OOA concentrations are high). The AMS size distribution during high HOA episodes features a bimodal distribution with contributions from particles with $d_{\mathrm{va}}<100 \mathrm{~nm}$, comparable to the HOA size distribution found by 3-D-factorization of mass spectra from Mexico City (Ulbrich et al., 2011) or based on tracer $\mathrm{m} / z$ (Nemitz et al., 2008). The discrepancy between AMS and SMPS size distributions at small particle sizes is characteristic of fractal particles (Slowik et al., 2004; DeCarlo et al., 2004), which are produced by combustion sources such as traffic emissions. Different sizing of fractal particles by the SMPS leads to an overestimation of the mass of these particles (DeCarlo et al., 2004). The size distribution during high COA periods resembles more the size distribution of particles during periods dominated by secondary OA, peaking at $\sim 350 \mathrm{~nm} d_{\mathrm{va}}$. A similar single-mode distribution was previously observed 

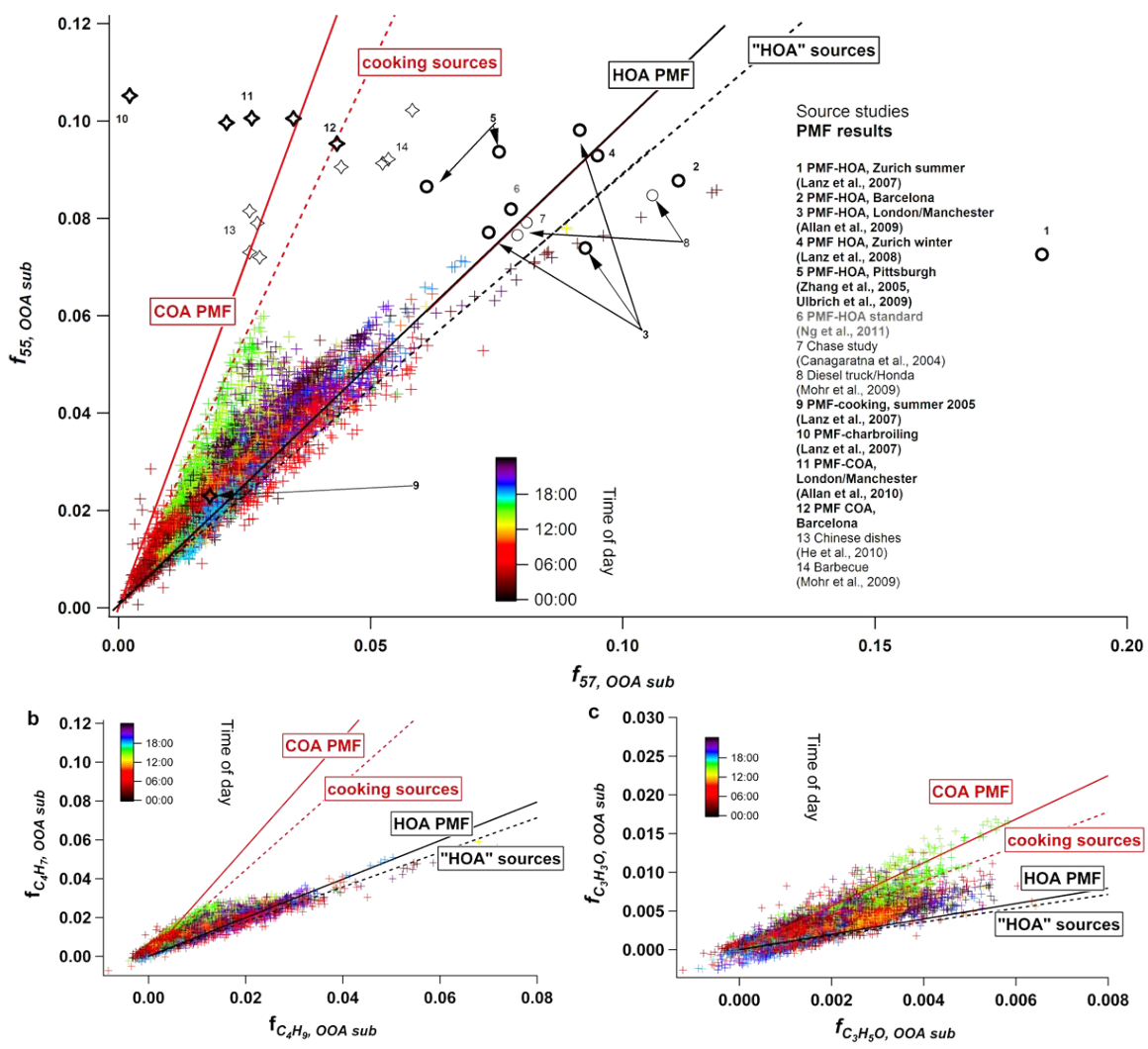

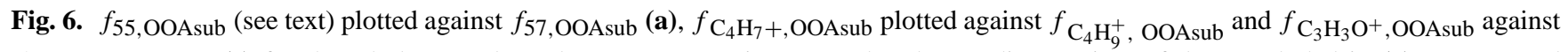
$f_{\mathrm{C}_{3} \mathrm{H}_{5} \mathrm{O}+\text {,OOAsub }}$ (c) for the whole Barcelona dataset. Data points are colored according to time of day. Included in (a) are $F_{55}$ and $F_{57}$ extracted from various PMF HOA and COA factors (bold symbols), as well as from cooking and traffic source emission studies (thin symbols), the lines represent the linear fits applied to each group. Note that axes are scaled differently for clarity reasons.

by Hildemann et al. (1991b) for meat cooking aerosol, with the peak center at around $200 \mathrm{~nm}$ mobility diameter. Rogge et al. (1991) explained the formation of PM from (meat) cooking activities by nucleation and growth of evaporated grease, which most likely yields spherical particles. For periods when BBOA dominates the organic composition, also ammonium nitrate concentrations are rather high. As shown in Fig. 4, BBOA is slightly increased during nighttime, when lower temperatures favor partitioning of semivolatile species such as nitrate into the particle phase. Consequently, the difference between SMPS and total AMS mass size distribution is especially distinct for BBOA episodes. The AMS size distribution peaks at $\sim 500 \mathrm{~nm}$, contributions from particles with a $d_{\mathrm{va}}$ of $\sim 200 \mathrm{~nm}$ can be observed as well.

\subsection{Cooking organic aerosol}

As described in Sect. 3.2.1, COA and HOA show clear differences in the ratio of oxygen-containing ions to reduced ions and thus in their degree of oxygenation. However, if only AMS UMR data is available, the detection of COA in ambient air can be difficult due to the similarity of its UMR spectrum with HOA (Mohr et al., 2009). This spectral similarity complicates efforts to resolve distinct HOA and COA factors by PMF and is a likely cause of the scarcity of COA factors resolved from urban AMS datasets (Lanz et al., 2007; Allan et al., 2010; Huang et al., 2010; Slowik et al., 2010; Crippa et al., 2012). However, the substantial contributions of COA to total organic $\mathrm{PM}_{1}$ suggest the importance of this anthropogenic activity to urban air quality. Here the spectral characteristics of HOA and COA discussed above are used to develop an approach for distinguishing and quantifying the contributions of HOA and COA to ambient aerosol.

\subsubsection{Organic mass fragments 55 and 57}

As stated earlier, the organic mass fragments $55(\mathrm{~m} / \mathrm{z} 55)$ and $57(\mathrm{~m} / \mathrm{z} 57)$ are crucial for the identification of COA and HOA, respectively. However, these fragments cannot directly serve as tracers because (1) each strongly appears in both factor mass spectra and (3) interferences from LV- and SV-OOA are present, which have to be subtracted (denoted by the subscript OOAsub). We therefore define the following 


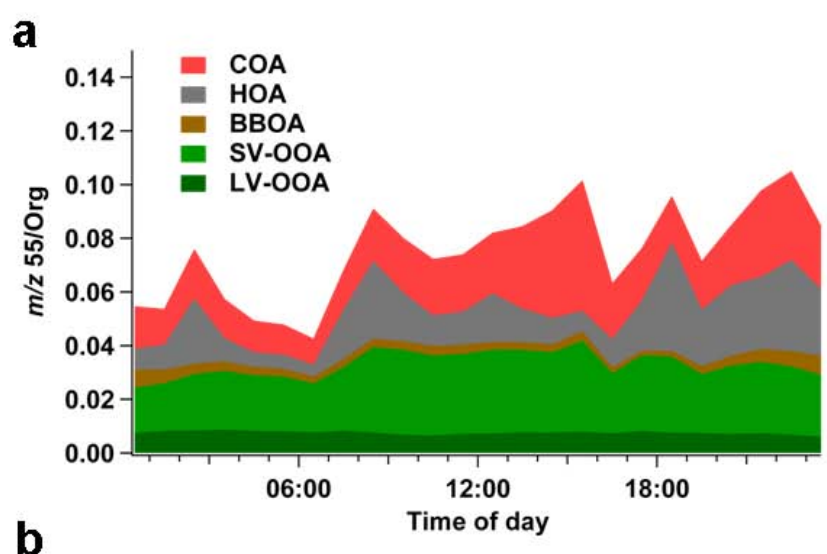

b

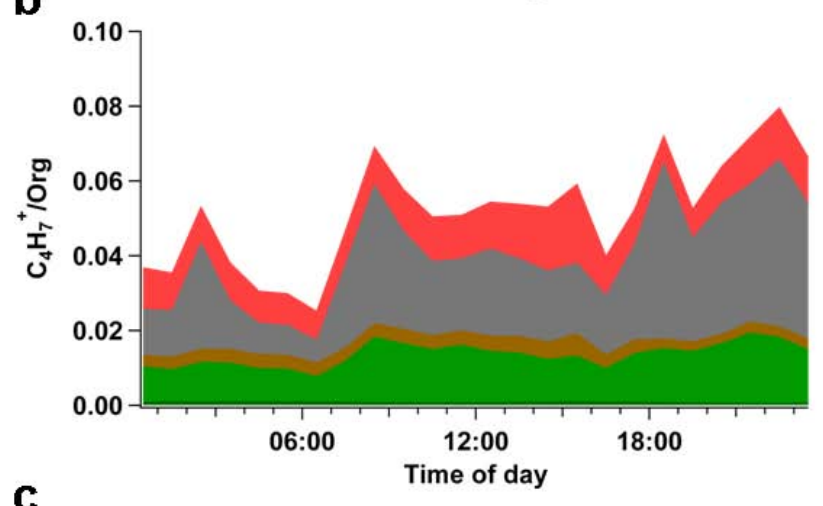

C

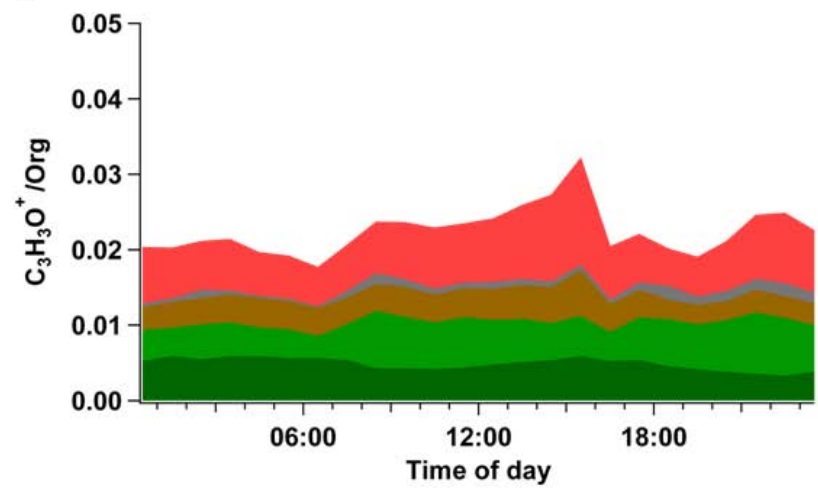

Fig. 7. Stacked diurnal cycle of the time series of the fractions of $m / z 55$ (a), $\mathrm{C}_{4} \mathrm{H}_{7}^{+}$(b), and $\mathrm{C}_{3} \mathrm{H}_{3} \mathrm{O}^{+}$(c) of LV-OOA, SV-OOA, $\mathrm{HOA}, \mathrm{COA}$, and BBOA, respectively, normalized to total organics.

quantities:

$f_{55, \mathrm{OOAsub}}=\left(m / z 55-m / z 55_{\mathrm{LV}-\mathrm{OOA}}-m / z 55_{\mathrm{SV}-\mathrm{OOA}}\right) / \mathrm{Org}$

$f_{57, \mathrm{OOAsub}}=\left(m / z 57-m / z 57_{\mathrm{LV}-\mathrm{OOA}}-m / z 57_{\mathrm{SV}-\mathrm{OOA}}\right) / \mathrm{Org}$

Contributions from LV- and SV-OOA are calculated as the product of the factor time series and the mass fraction of the selected $\mathrm{m} / \mathrm{z}$ in the factor mass spectrum. Figure $6 \mathrm{a}$

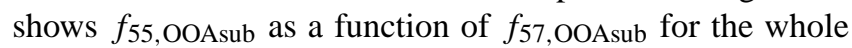
Barcelona dataset. The data points fall into a $\mathrm{V}$-shape in the scatter plot; subtraction of the LV- and SV-OOA interferences changed the intercept to 0 (compare Fig. S25) but did not otherwise alter the result. Data points are colored by time of day. The $f_{55, \text { OOAsub }} / f_{57, \text { OOAsub }}$ slope is steepest in the afternoon, corresponding to the peak in the COA diurnal pattern (see Fig. 4). In contrast, the shallowest slopes are found in the road traffic-dominated morning and evening hours.

Figure 6a also includes $F_{55}$ (defined as $m / z, 55 / O r g$ ) and $F_{57}(\mathrm{~m} / \mathrm{z}, 57 / \mathrm{Org})$ from PMF HOA and COA factors (bold symbols), as well as from emission spectra of cooking and road traffic sources (thin symbols). These factors/sources were grouped as "cooking-like" or "traffic-like", and a linear fit was applied to each group. Point \#1, Zurich Summer PMF-HOA (Lanz et al., 2007), was excluded as an outlier. Fits to the cooking-like (red solid and dotted lines) and traffic-like (black solid and dotted lines) follow the higher and lower edges of the Barcelona data in Fig. 6a, which correspond to cooking- and traffic-influenced data, respectively. This supports the use of the $f_{55, \text { OOAsub }} / f_{57, \text { OOAsub }}$ ratio as a metric for identifying COA.

Figure 2 shows that $m / z, 55$ for HOA is composed mostly of a different ion $\left(\mathrm{C}_{4} \mathrm{H}_{7}^{+}\right)$than $\mathrm{COA}\left(\mathrm{C}_{4} \mathrm{H}_{7}^{+}\right.$and $\left.\mathrm{C}_{3} \mathrm{H}_{3} \mathrm{O}^{+}\right)$. High resolution source spectra show consistent results; see Fig. S26. Similarly, for $\mathrm{HOA} m / z 57$ is composed of $\mathrm{C}_{4} \mathrm{H}_{9}^{+}$ while COA $m / z, 57$ includes both $\mathrm{C}_{4} \mathrm{H}_{9}^{+}$and $\mathrm{C}_{3} \mathrm{H}_{5} \mathrm{O}^{+}$. A simplified apportionment of these ions is assessed in Fig. $6 \mathrm{~b}$ and $\mathrm{c}$, where $\mathrm{C}_{3} \mathrm{H}_{3} \mathrm{O}^{+}$and $\mathrm{C}_{3} \mathrm{H}_{5} \mathrm{O}^{+}$are apportioned to COA, with $\mathrm{C}_{4} \mathrm{H}_{7}^{+}$and $\mathrm{C}_{4} \mathrm{H}_{9}^{+}$apportioned entirely to HOA. These figures are similar to Fig. $6 \mathrm{a}$, with $f_{55}$,OOAsub and $f_{57, \text { OOAsub }}$ replaced by $f_{\mathrm{C}_{4} \mathrm{H}_{7}^{+} \text {, OOAsub }}$ and $f_{\mathrm{C}_{4} \mathrm{H}_{9}{ }^{+} \text {,OOAsub }}$ in

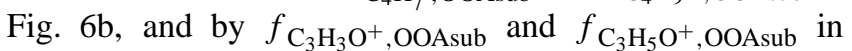
Fig. 6c. Solid and dashed lines are the same as in Fig. 6a. HOA and COA are much less distinguishable in Fig. 6b than for the UMR data (6a), with the data points mostly aligned to the HOA fit line. This results from the low ratio of $f_{\mathrm{C}_{4} \mathrm{H}_{7}^{+} \text {,OOAsub }}$ to $f_{\mathrm{C}_{4} \mathrm{H}_{9}^{+} \text {, OOAsub }}$. In contrast, Fig. 6c

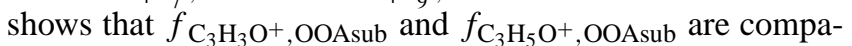
rable to the UMR data in their ability to distinguish HOA and COA, indicating that the spectral differences are driven by the oxygen-containing ions. The fractional contribution of each PMF factor to $m / z, 55, \mathrm{C}_{4} \mathrm{H}_{7}^{+}$, and $\mathrm{C}_{3} \mathrm{H}_{3} \mathrm{O}^{+}$is shown in Fig. 7 as a stacked diurnal cycle. The top panel (a) shows only small contributions from LV-OOA and BBOA to $m / z$ 55. Although SV-OOA contributions are larger, SVOOA is readily distinguished by high $\mathrm{m} / \mathrm{z} 44$ allowing the SVOOA contribution to $\mathrm{m} / \mathrm{z} 55$ to be subtracted as done above. HOA has significant signal at $m / z 55$, however, as discussed above, HOA and COA can be distinguished by the oxygencontaining organic ions of $\mathrm{m} / \mathrm{z} 55$ and 57. This is shown in Fig. $7 \mathrm{~b}$ and c: $\mathrm{C}_{3} \mathrm{H}_{3} \mathrm{O}^{+}$shows lower signal than $\mathrm{C}_{4} \mathrm{H}_{7}^{+}$, but that signal is dominated by $\mathrm{COA}$ emissions and is thus a more useful tracer. 
a

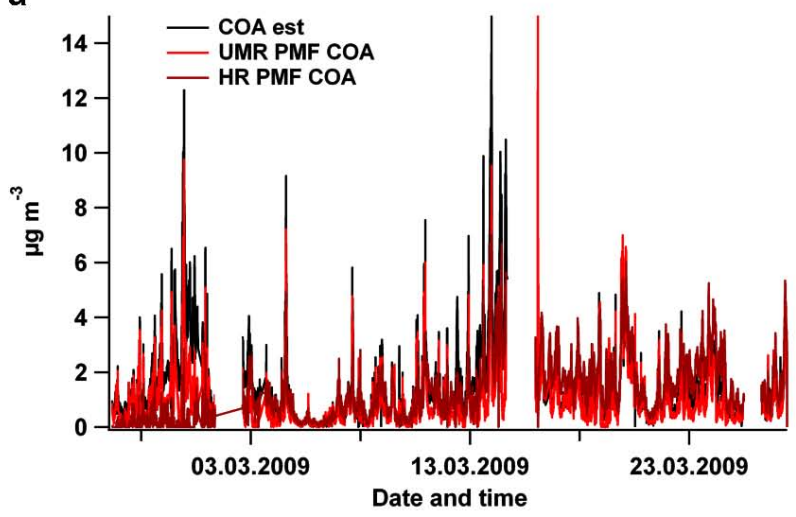

b

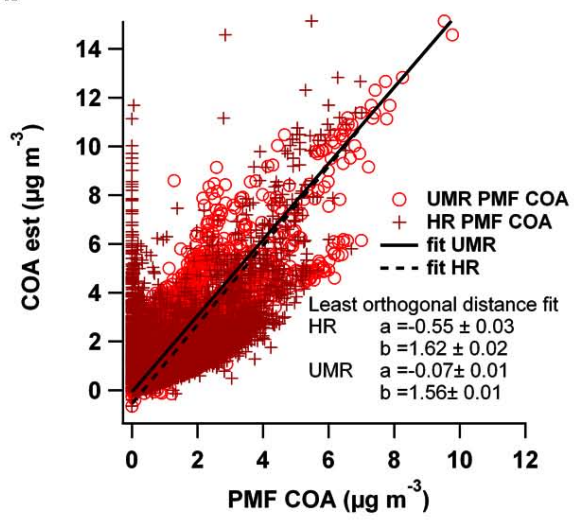

Fig. 8. Comparison of PMF COA and COA estimated using organic mass fragments 55, 57, and 44 (COA est), time series (a) and scatterplot of time series (b).

\subsubsection{Estimation of COA from $m / z, 55$}

In this section a simple approximation to estimate the COA concentration based on the time series of the organic mass fragments 55, 57, and 44 is provided. Similar methods to estimate HOA, BBOA, and OOA concentrations have been given by Aiken et al. (2009). As described in the previous section, $m / z 55$ can be used as a tracer for COA, even though its signal also has contributions from the other factors, mostly HOA and OOA (Eq. 2). BBOA can contribute as well to $\mathrm{m} / \mathrm{z}, 55$; however, due to the high variability wood burning spectra (Weimer et al., 2008) and the low BBOA concentrations in Barcelona it was not considered in the estimation.

$m / z 55=m / z 55(\mathrm{COA})+m / z 55(\mathrm{HOA})+m / z 55(\mathrm{OOA})$

Consequently, the contributions from the other factors have to be subtracted and the remaining $m / z 55(\mathrm{COA})$ has to be scaled up by a factor $q$ to yield the estimated COA concentration $\mathrm{COA}_{\mathrm{est}}$,

$\mathrm{COA}_{\mathrm{est}}=q \times m / z 55(\mathrm{COA})$

The contribution from OOA to $m / z 55$ is assumed to be linear with $m / z$ 44,

$m / z 55(\mathrm{OOA})=b \times m / z 44$

where

$b=\frac{F_{55, \mathrm{OOA}}}{F_{44, \mathrm{OOA}}}$

$F_{55, \text { OOA }}$ denotes the signal at $m / z, 55$ in the OOA mass spectrum normalized to the sum of the spectrum.

The contribution from HOA to $m / z 55$ is assumed to be linear with $m / z, 57$,

$m / z 55(\mathrm{HOA})=a \times m / z 57(\mathrm{HOA})$ where

$a=\frac{F_{55, \mathrm{HOA}}}{F_{57, \mathrm{HOA}}}$

$m / z 57$ can have contributions not only from HOA, but also from COA and OOA; thus:

$m / z 57(\mathrm{HOA})=m / z 57-m / z 57(\mathrm{COA})-m / z 57(\mathrm{OOA})$

The last term in Eq. (9) is again linear with $m / z$ 44, with the coefficient

$c=\frac{F_{57, \mathrm{OOA}}}{F_{44, \mathrm{OOA}}}$

With

$m / z 57(\mathrm{COA})=\frac{1}{d} \times m / z 55(\mathrm{COA})$

$d=\frac{F_{55, \mathrm{COA}}}{F_{57, \mathrm{COA}}}$

Eq. (4) can be solved as

$\mathrm{COA}_{\mathrm{est}}=q \times\left[\frac{\frac{1}{a} m / z 55-m / z 57+\left(c-\frac{b}{a}\right) m / z 44}{\frac{1}{a}-\frac{1}{d}}\right]$

with

$q=\frac{1}{F_{55, \mathrm{COA}}}$

The coefficients $a, b, c, d$, and $q$ were estimated using the PMF factor mass spectra from this study and those published in Allan et al. (2010), and Crippa et al. (2011): $q=11 \pm 2 ; a=0.9 \pm 0.2 ; b=0.15 \pm 0.1 ; c=0.07 \pm 0.07$; and $d=3.0 \pm 0.7$. The approach was tested with the present data set. Figure 8 shows a comparison of PMF COA (both UMR and $\mathrm{HR}$ ) found here with $\mathrm{COA}_{\text {est }}$ calculated using Eq. (13). Overall, the agreement is good: The correlation of the UMR 
PMF COA time series and $\mathrm{COA}_{\text {est }}$ yields an $R^{2}$ of 0.7 ; the $R^{2}$ of the correlation with the HR solution is lower $(0.32)$ due to the period in the beginning, until 02 March 2009 (compare Sect. 3.2.1). Removing the Barcelona data $(a=0.8, b=0.12$, $c=0.03, d=2.2$, and $q=10$ ) from the average coefficients calculation did not change the values for $a, b, c, d$, and $q$; thus, the comparison between $\mathrm{COA}_{\text {est }}$ and PMF COA is not positively biased by the double use of the same data set. The application of this approach to other datasets and the comparison of coefficient values will be of great interest, as discrepancies can also be influenced by some variation of mass spectral patterns between different instruments.

\section{Conclusions}

Several studies confirm the possible importance of cooking activities as a major contributor to urban aerosol loadings; however, the number of urban environments where COA was detected and quantified is still very low. A reason for that might be the similarity of AMS UMR spectra of HOA and COA. This paper presents an approach to detect cooking organic aerosol (COA) in ambient datasets and a simple method based on organic mass fragments 55, 57, and 44 measured by AMS to estimate COA concentrations.

AMS data were acquired at an urban background site in Barcelona, Spain, during March 2009, in order to investigate the specific high PM winter anticyclone episodes. PMF analysis revealed 5 factors or sources contributing to OA: LV-OOA, related to regional, aged secondary OA; SVOOA, an early-generation secondary OA with substantial contributions from immediately formed secondary or oxidized primary OA from vehicle emissions; HOA (primary hydrocarbon-like OA, again related to traffic and possibly ship emissions); BBOA from domestic heating or agricultural wood burning activities; and COA (cooking organic aerosol). From these results we estimate that POA in Barcelona has a non-fossil carbon fraction of about $59 \%$, which helps explain the high non-fossil fraction of OC observed during DAURE.

The COA HR spectrum contains considerable signal from oxygenated ions whereas the HR HOA spectrum has almost exclusively contributions from chemically reduced ions, however, on a UMR basis, the spectral patterns are very similar. Plotting $\mathrm{m} / \mathrm{z} 55$ normalized to total organics against $\mathrm{m} / \mathrm{z} 57$ normalized to total organics helps identify COA in ambient datasets: The data points fall into a V-shape, with HOA-influenced data aligned to the lower arm, a line defined by fitting $F_{55}$ and $F_{57}$ from various PMF HOA and vehicle emissions spectra; $\mathrm{COA}$ influenced data points lie on the upper arm of the V-shape denoted by a fit of $F_{55}$ and $F_{57}$ from PMF COA factors and cooking emissions spectra. HR data show that this differentiation is mainly driven by the oxygen-containing ions $\mathrm{C}_{3} \mathrm{H}_{3} \mathrm{O}^{+}$and $\mathrm{C}_{3} \mathrm{H}_{5} \mathrm{O}^{+} . \mathrm{C}_{3} \mathrm{H}_{3} \mathrm{O}^{+}$ shows lower signal than $\mathrm{C}_{4} \mathrm{H}_{7}^{+}$, but that signal is to a larger extent from COA emissions than that from $\mathrm{C}_{4} \mathrm{H}_{7}^{+}$compared to the other factors, and thus helps identifying the COA factor much better than $\mathrm{C}_{4} \mathrm{H}_{7}^{+}$.

The agreement of COA estimated based on mass fragments 55, 57, and 44 and the PMF COA is satisfying for the present dataset. The application of this approach to other datasets will be of great interest to validate the coefficients determined in this study.

COA contributes $17 \%$ to organic PM in Barcelona during the winter anticyclonic pollution episodes, consistent with the high non-fossil fraction of carbonaceous $\mathrm{PM}_{1}$ found by ${ }^{14} \mathrm{C}$ analysis. This is a significant fraction with consequences for human health; even more so since cooking is usually an indoor activity and what is being measured at an urban background site is already significantly diluted compared to the emission sites. The study emphasizes the significance of cooking activities for ambient air quality and confirms the importance of chemical composition measurements with a high mass and time resolution.

\section{Supplementary material related to this article is available online at: http://www.atmos-chem-phys.net/12/1649/2012/ acp-12-1649-2012-supplement.pdf.}

Acknowledgements. We thank the organizers of the DAURE project, including Mar Viana and everybody else at ICTJA for their work and help. We acknowledge the CCES project IMBALANCE and the EU-FP7 project EUCAARI for financial support and 'Accion Complementaria DAURE' from the Spanish Ministry of Science and Innovation (CGL2007-30502-E/CLI) for infrastructure support. P. F. DeCarlo is grateful for the postdoctoral support from the US-NSF (IRFP\# 0701013). J. Peñuelas and R. Seco were supported by the Spanish Government projects CGL2010-17172 and Consolider Ingenio Montes CSD2008-00040, and by a postdoctoral grant from Fundación Ramón Areces to R. Seco. The National Center for Atmospheric Research is sponsored by the National Science Foundation. J. L. Jimenez was supported by NSF ATM0919189 and DOE (BER, ASR program) DE-FG02-11ER65293.

Edited by: L. Molina

\section{References}

Aiken, A. C., DeCarlo, P. F., Kroll, J. H., Worsnop, D. R., Huffman, J. A., Docherty, K. S., Ulbrich, I. M., Mohr, C., Kimmel, J. R., Sueper, D., Sun, Y., Zhang, Q., Trimborn, A., Northway, M., Ziemann, P. J., Canagaratna, M. R., Onasch, T. B., Alfarra, M. R., Prevot, A. S. H., Dommen, J., Duplissy, J., Metzger, A., Baltensperger, U., and Jimenez, J. L.: O/C and OM/OC ratios of primary, secondary, and ambient organic aerosols with high-resolution time-of-flight aerosol mass spectrometry, Environ. Sci. Technol., 42, 4478-4485, doi:10.1021/Es703009q, 2008. 
Aiken, A. C., Salcedo, D., Cubison, M. J., Huffman, J. A., DeCarlo, P. F., Ulbrich, I. M., Docherty, K. S., Sueper, D., Kimmel, J. R., Worsnop, D. R., Trimborn, A., Northway, M., Stone, E. A., Schauer, J. J., Volkamer, R. M., Fortner, E., de Foy, B., Wang, J., Laskin, A., Shutthanandan, V., Zheng, J., Zhang, R., Gaffney, J., Marley, N. A., Paredes-Miranda, G., Arnott, W. P., Molina, L. T., Sosa, G., and Jimenez, J. L.: Mexico City aerosol analysis during MILAGRO using high resolution aerosol mass spectrometry at the urban supersite (T0) - Part 1: Fine particle composition and organic source apportionment, Atmos. Chem. Phys., 9, 66336653, doi:10.5194/acp-9-6633-2009, 2009.

Ajuntament de Barcelona: Dades bàsiques 2006, Direcció de serveis de mobilitat, Barcelona, 2007.

Alfarra, M. R., Prevot, A. S. H., Szidat, S., Sandradewi, J., Weimer, S., Lanz, V. A., Schreiber, D., Mohr, M., and Baltensperger, U.: Identification of the mass spectral signature of organic aerosols from wood burning emissions, Environ. Sci. Technol., 41, 57705777, 2007.

Allan, J. D., Williams, P. I., Morgan, W. T., Martin, C. L., Flynn, M. J., Lee, J., Nemitz, E., Phillips, G. J., Gallagher, M. W., and Coe, H.: Contributions from transport, solid fuel burning and cooking to primary organic aerosols in two UK cities, Atmos. Chem. Phys., 10, 647-668, doi:10.5194/acp-10-647-2010, 2010.

Andreae, M. O.: A new look at aging aerosols, Science, 326, 14931494, doi:10.1126/science.1183158, 2009.

Baltensperger, U., Chirico, R., DeCarlo, P. F., Dommen, J., Gaeggeler, K., Heringa, M. F., Li, M. L., Prevot, A. S. H., Alfarra, M. R., Gross, D. S., and Kalberer, M.: Recent developments in the mass spectrometry of atmospheric aerosols, Eur. J. Mass Spectrom., 16, 389-395, 2010.

Canagaratna, M. R., Jayne, J. T., Ghertner, D. A., Herndon, S., Shi, Q., Jimenez, J. L., Silva, P. J., Williams, P., Lanni, T., Drewnick, F., Demerjian, K. L., Kolb, C. E., and Worsnop, D. R.: Chase studies of particulate emissions from in-use New York City vehicles, Aerosol. Sci. Technol., 38, 555-573, 2004.

Canagaratna, M. R., Jayne, J. T., Jimenez, J. L., Allan, J. D., Alfarra, M. R., Zhang, Q., Onasch, T. B., Drewnick, F., Coe, H., Middlebrook, A., Delia, A., Williams, L. R., Trimborn, A. M., Northway, M. J., DeCarlo, P. F., Kolb, C. E., Davidovits, P., and Worsnop, D. R.: Chemical and microphysical characterization of ambient aerosols with the Aerodyne aerosol mass spectrometer, Mass Spectrom. Rev., 26, 185-222, 2007.

Capes, G., Johnson, B., McFiggans, G., Williams, P. I., Haywood, J., and Coe, H.: Aging of biomass burning aerosols over West Africa: Aircraft measurements of chemical composition, microphysical properties, and emission ratios, J. Geophys. ResAtmos., 113, D00C15, doi:10.1029/2008JD009845, 2008.

Cass, G. R.: Organic molecular tracers for particulate air pollution sources, TRAC-Trend. Anal. Chem., 17, 356-366, 1998.

Chirico, R., DeCarlo, P. F., Heringa, M. F., Tritscher, T., Richter, R., Prévôt, A. S. H., Dommen, J., Weingartner, E., Wehrle, G., Gysel, M., Laborde, M., and Baltensperger, U.: Impact of aftertreatment devices on primary emissions and secondary organic aerosol formation potential from in-use diesel vehicles: results from smog chamber experiments, Atmos. Chem. Phys., 10, 11545-11563, doi:10.5194/acp-10-11545-2010, 2010.

Crippa, M., DeCarlo, P. F., Mohr, C., Heringa, M. F., Chirico,R., Slowik, J. G., Poulain, L., Wiedensohler, A., Freutel, F.,Drewnick, F., Schneider, J., Di Marco, C. F., Nemitz, E., Zim-
mermann,R., Elsässer, M., Prévôt, A. S. H., and Baltensperger, U.: Wintertime aerosols chemical composition and source apportionmentin the metropolitan area of Paris, in preparation, 2012.

DeCarlo, P. F., Slowik, J. G., Worsnop, D. R., Davidovits, P., and Jimenez, J. L.: Particle morphology and density characterization by combined mobility and aerodynamic diameter measurements. Part 1, Theory Aerosol. Sci. Technol., 38, 1185-1205, doi:10.1080/027868290903907, 2004.

DeCarlo, P. F., Kimmel, J. R., Trimborn, A., Northway, M. J., Jayne, J. T., Aiken, A. C., Gonin, M., Fuhrer, K., Horvath, T., Docherty, K. S., Worsnop, D. R., and Jimenez, J. L.: Field-deployable, high-resolution, time-of-flight aerosol mass spectrometer, Anal. Chem., 78, 8281-8289, 2006.

DeCarlo, P. F., Ulbrich, I. M., Crounse, J., de Foy, B., Dunlea, E. J., Aiken, A. C., Knapp, D., Weinheimer, A. J., Campos, T., Wennberg, P. O., and Jimenez, J. L.: Investigation of the sources and processing of organic aerosol over the Central Mexican Plateau from aircraft measurements during MILAGRO, Atmos. Chem. Phys., 10, 5257-5280, doi:10.5194/acp-10-52572010, 2010.

Docherty, K. S., Aiken, A. C., Huffman, J. A., Ulbrich, I. M., DeCarlo, P. F., Sueper, D., Worsnop, D. R., Snyder, D. C., Grover, B. D., Eatough, D. J., Goldstein, A. H., Ziemann, P. J., and Jimenez, J. L.: The 2005 Study of Organic Aerosols at Riverside (SOAR-1): instrumental intercomparisons and fine particle composition, Atmos. Chem. Phys. Discuss., 11, 6301-6362, doi:10.5194/acpd-11-6301-2011, 2011.

Drewnick, F., Hings, S. S., DeCarlo, P., Jayne, J. T., Gonin, M., Fuhrer, K., Weimer, S., Jimenez, J. L., Demerjian, K. L., Borrmann, S., and Worsnop, D. R.: A new time-of-flight aerosol mass spectrometer (TOF-AMS) - Instrument description and first field deployment, Aerosol. Sci. Technol., 39, 637-658, 2005.

Duplissy, J., DeCarlo, P. F., Dommen, J., Alfarra, M. R., Metzger, A., Barmpadimos, I., Prevot, A. S. H., Weingartner, E., Tritscher, T., Gysel, M., Aiken, A. C., Jimenez, J. L., Canagaratna, M. R., Worsnop, D. R., Collins, D. R., Tomlinson, J., and Baltensperger, U.: Relating hygroscopicity and composition of organic aerosol particulate matter, Atmos. Chem. Phys., 11, 1155-1165, doi:10.5194/acp-11-1155-2011, 2011.

Farmer, D. K., Matsunaga, A., Docherty, K. S., Surratt, J. D., Seinfeld, J. H., Ziemann, P. J., and Jimenez, J. L.: Response of an aerosol mass spectrometer to organonitrates and organosulfates and implications for atmospheric chemistry, P. Natl. A Sci. India, 107, 6670-6675, doi:10.1073/pnas.0912340107, 2010.

Fortmann, R., Kariher, P., and Clayton, R.: Indoor air quality: Residential cooking exposures. Final report., State of California Air Resources Board, Research Division, Sacramento, CA, 2001.

Goldstein, A. H. and Galbally, I. E.: Known and unexplored organic constituents in the earth's atmosphere, Environ. Sci. Technol., 41, 1514-1521, 2007.

Grantz, D. A., Garner, J. H. B., and Johnson, D. W.: Ecological effects of particulate matter, Environ. Int., 29, 213-239, doi:10.1016/s0160-4120(02)00181-2, 2003.

Gray, H. A.: Control of atmospheric fine primary carbon particle concentrations. Final report for California Air Resources Board., Environmental Quality Laboratory, California Institute of Technology, Pasadena, 353 pp., 1986.

Gysel, M., Crosier, J., Topping, D. O., Whitehead, J. D., Bower, K. 
N., Cubison, M. J., Williams, P. I., Flynn, M. J., McFiggans, G. B., and Coe, H.: Closure study between chemical composition and hygroscopic growth of aerosol particles during TORCH2, Atmos. Chem. Phys., 7, 6131-6144, doi:10.5194/acp-7-61312007, 2007.

Hallquist, M., Wenger, J. C., Baltensperger, U., Rudich, Y., Simpson, D., Claeys, M., Dommen, J., Donahue, N. M., George, C., Goldstein, A. H., Hamilton, J. F., Herrmann, H., Hoffmann, T., Iinuma, Y., Jang, M., Jenkin, M. E., Jimenez, J. L., Kiendler-Scharr, A., Maenhaut, W., McFiggans, G., Mentel, Th. F., Monod, A., Prévôt, A. S. H., Seinfeld, J. H., Surratt, J. D., Szmigielski, R., and Wildt, J.: The formation, properties and impact of secondary organic aerosol: current and emerging issues, Atmos. Chem. Phys., 9, 5155-5236, doi:10.5194/acp-95155-2009, 2009.

He, L.-Y., Hu, M., Huang, X.-F., Yu, B.-D., Zhang, Y.-H., and Liu, D.-Q.: Measurement of emissions of fine particulate organic matter from Chinese cooking, Atmos. Environ., 38, 6557-6564, 2004.

He, L.-Y., Lin, Y., Huang, X.-F., Guo, S., Xue, L., Su, Q., Hu, M., Luan, S.-J., and Zhang, Y.-H.: Characterization of highresolution aerosol mass spectra of primary organic aerosol emissions from Chinese cooking and biomass burning, Atmos. Chem. Phys., 10, 11535-11543, doi:10.5194/acp-10-11535-2010, 2010.

Herich, H., Hueglin, C., and Buchmann, B.: A 2.5 year's source apportionment study of black carbon from wood burning and fossil fuel combustion at urban and rural sites in Switzerland, Atmos. Meas. Tech., 4, 1409-1420, doi:10.5194/amt-4-1409-2011, 2011.

Hildemann, L. M., Markowski, G. R., and Cass, G. R.: Chemical composition of emissions from urban sources of fine organic aerosol, Environ. Sci. Technol., 25, 744-759, 1991a.

Hildemann, L. M., Markowski, G. R., Jones, M. C., and Cass, G. R.: Submicrometer aerosol mass distributions of emissions from boilers, fireplaces, automobiles, diesel trucks, and meat-cooking operations, Aerosol. Sci. Technol., 14, 138-152, 1991 b.

Huang, X.-F., He, L.-Y., Hu, M., Canagaratna, M. R., Sun, Y., Zhang, Q., Zhu, T., Xue, L., Zeng, L.-W., Liu, X.-G., Zhang, Y.-H., Jayne, J. T., Ng, N. L., and Worsnop, D. R.: Highly time-resolved chemical characterization of atmospheric submicron particles during 2008 Beijing Olympic Games using an Aerodyne High-Resolution Aerosol Mass Spectrometer, Atmos. Chem. Phys., 10, 8933-8945, doi:10.5194/acp-10-8933-2010, 2010.

IPCC: Fourth Assessment Report: The Physical Science Basis, Working Group I, Final Report, Geneva, Switzerland, available at: http://www.ipcc.ch/ipccreports/ar4-wg1.htm, 2007.

Jimenez, J. L., Canagaratna, M. R., Donahue, N. M., Prevot, A. S. H., Zhang, Q., Kroll, J. H., DeCarlo, P. F., Allan, J. D., Coe, H., Ng, N. L., Aiken, A. C., Docherty, K. S., Ulbrich, I. M., Grieshop, A. P., Robinson, A. L., Duplissy, J., Smith, J. D., Wilson, K. R., Lanz, V. A., Hueglin, C., Sun, Y. L., Tian, J., Laaksonen, A., Raatikainen, T., Rautiainen, J., Vaattovaara, P., Ehn, M., Kulmala, M., Tomlinson, J. M., Collins, D. R., Cubison, M. J., Dunlea, E. J., Huffman, J. A., Onasch, T. B., Alfarra, M. R., Williams, P. I., Bower, K., Kondo, Y., Schneider, J., Drewnick, F., Borrmann, S., Weimer, S., Demerjian, K., Salcedo, D., Cottrell, L., Griffin, R., Takami, A., Miyoshi, T., Hatakeyama, S., Shimono, A., Sun, J. Y., Zhang, Y. M., Dzepina, K., Kimmel, J.
R., Sueper, D., Jayne, J. T., Herndon, S. C., Trimborn, A. M., Williams, L. R., Wood, E. C., Middlebrook, A. M., Kolb, C. E., Baltensperger, U., and Worsnop, D. R.: Evolution of organic aerosols in the atmosphere, Science, 326, 1525-1529, 2009.

Jorba, O., Pandolfi, M., Spada, M., Baldasano, J. M., Pey, J., Alastuey, A., Arnold, D., Sicard, M., Artiñano, B., Revuelta, M. A., and Querol, X.: The DAURE field campaign: meteorological overview, Atmos. Chem. Phys. Discuss., 11, 4953-5001, doi:10.5194/acpd-11-4953-2011, 2011.

Lanz, V. A., Alfarra, M. R., Baltensperger, U., Buchmann, B., Hueglin, C., and Prévôt, A. S. H.: Source apportionment of submicron organic aerosols at an urban site by factor analytical modelling of aerosol mass spectra, Atmos. Chem. Phys., 7, 1503-1522, doi:10.5194/acp-7-1503-2007, 2007.

Lanz, V. A., Alfarra, M. R., Baltensperger, U., Buchmann, B., Hueglin, C., Szidat, S., Wehrli, M. N., Wacker, L., Weimer, S., Caseiro, A., Puxbaum, H., and Prevot, A. S. H.: Source attribution of submicron organic aerosols during wintertime inversions by advanced factor analysis of aerosol mass spectra, Environ. Sci. Technol., 42, 214-220, doi:10.1021/Es0707207, 2008.

Lanz, V. A., Prévôt, A. S. H., Alfarra, M. R., Weimer, S., Mohr, C., DeCarlo, P. F., Gianini, M. F. D., Hueglin, C., Schneider, J., Favez, O., D'Anna, B., George, C., and Baltensperger, U.: Characterization of aerosol chemical composition with aerosol mass spectrometry in Central Europe: an overview, Atmos. Chem. Phys., 10, 10453-10471, doi:10.5194/acp-10-10453-2010, 2010.

Middlebrook, A. M., Bahreini, R., Jimenez, J. L., and Canagaratna, M. R.: Evaluation of composition-dependent collection efficiencies for the Aerodyne aerosol mass spectrometer using field data, Aerosol. Sci. Technol., 46, 258-271, doi:10.1080/02786826.2011.620041, 2011.

Minguillón, M. C., Perron, N., Querol, X., Szidat, S., Fahrni, S., Alastuey, A., Jimenez, J. L., Mohr, C., Ortega, A., Day, D. A., Lanz, V. A., Wacker, L., Reche, C., Cusack, M., Amato, F., Kiss, G., Hoffer, A., Decesari, S., Moretti, F., Hillamo, R., Teinilä, K., Seco, R., Peñuelas, J., Metzger, A., Schallhart, S., Müller, M., Hansel, A., Burkhart, J., Baltensperger, U., and Prevot, A. S. H.: Fossil versus contemporary sources of fine elemental and organic carbonaceous particulate matter during the DAURE campaign in Northeast Spain, Atmos. Chem. Phys., 11, 12067-12084, 10,

http://www.atmos-chem-phys.net/11/12067/10/.5194/acp-1112067-2011, 2011.

Mohr, C., Huffman, J. A., Cubison, M. J., Aiken, A. C., Docherty, K. S., Kimmel, J. R., Ulbrich, I. M., Hannigan, M., and Jimenez, J. L.: Characterization of primary organic aerosol emissions from meat cooking, trash burning, and motor vehicles with highresolution aerosol mass spectrometry and comparison with ambient and chamber observations, Environ. Sci. Technol., 43, 24432449, 2009.

Mohr, C., Richter, R., DeCarlo, P. F., Prévôt, A. S. H., and Baltensperger, U.: Spatial variation of chemical composition and sources of submicron aerosol in Zurich during wintertime using mobile aerosol mass spectrometer data, Atmos. Chem. Phys., 11, 7465-7482, doi:10.5194/acp-11-7465-2011, 2011.

Murphy, D. M., Cziczo, D. J., Froyd, K. D., Hudson, P. K., Matthew, B. M., Middlebrook, A. M., Peltier, R. E., Sullivan, A., Thomson, D. S., and Weber, R. J.: Single-particle mass spectrometry of tropospheric aerosol particles, J. Geophys. Res., 111, D23S32, 
doi:10.1029/2006JD007340, 2006.

Murphy, S. M., Agrawal, H., Sorooshian, A., Padró, L. T., Gates, H., Hersey, S., Welch, W. A., Jung, H., Miller, J. W., Cocker, D. R., Nenes, A., Jonsson, H. H., Flagan, R. C., and Seinfeld, J. H.: Comprehensive simultaneous shipboard and airborne characterization of exhaust from a modern container ship at sea, Environ. Sci. Technol., 43, 4626-4640, 2009.

Nel, A.: Air pollution-related illness: Effects of particles, Science, 308, 804-806, doi:10.1126/science.1108752, 2005.

Nemitz, E., Jimenez, J. L., Huffman, J. A., Ulbrich, I. M., Canagaratna, M. R., Worsnop, D. R., and Guenther, A. B.: An Eddycovariance system for the measurement of surface/atmosphere exchange fluxes of submicron aerosol chemical species - First application above an urban area, Aerosol. Sci. Technol., 42, 636657, 2008.

Nemitz, E., Prevot, A. S. H., Äijälä, M., Allan, J. D., Berresheim, H., Carbone, S., Canagaratna, M. R., Capes, G., Ceburnis, D., Choularton, T., Coe, H., Cubison, M. J., Dall'Osto, M., Di Marco, C. F., DeCarlo, P. F., Ehn, M., Eriksson, A., Freney, E., Herrmann, H., Jimenez, J. L., Hildebrandt, L., Juninen, H., Kiendler-Scharr, A., Laaksonen, A., Lanz, V. A., McFiggans, G., Mensah, A., Mentel, T. F., Mohr, C., O'Dowd, C., Ortega, A., Ovadnevaite, J., Pagels, J., Pandis, S. N., Phillips, G. J., Poulain, L., Raatikainen, T., Saarikoski, S., Sellegri, K., Spindler, G., Sueper, D., Swietlicki, E., Tiitta, P., and Worsnop, D. R.: European submicron aerosol chemical composition derived from a campaign-based Aerosol Mass Spectrometer network, in preparation, 2012.

Ng, N. L., Canagaratna, M. R., Zhang, Q., Jimenez, J. L., Tian, J., Ulbrich, I. M., Kroll, J. H., Docherty, K. S., Chhabra, P. S., Bahreini, R., Murphy, S. M., Seinfeld, J. H., Hildebrandt, L., Donahue, N. M., DeCarlo, P. F., Lanz, V. A., Prévôt, A. S. H., Dinar, E., Rudich, Y., and Worsnop, D. R.: Organic aerosol components observed in Northern Hemispheric datasets from Aerosol Mass Spectrometry, Atmos. Chem. Phys., 10, 46254641, doi:10.5194/acp-10-4625-2010, 2010.

Ng, N. L., Canagaratna, M. R., Jimenez, J. L., Zhang, Q., Ulbrich, I. M., and Worsnop, D. R.: Real-time methods for estimating organic component mass concentrations from aerosol mass spectrometer data, Environ. Sci. Technol., 45, 910-916, 2011 a.

Ng, N. L., Herndon, S. C., Trimborn, A., Canagaratna, M. R., Croteau, P. L., Onasch, T. B., Sueper, D., Worsnop, D. R., Zhang, Q., Sun, Y. L., and Jayne, J. T.: An aerosol chemical speciation monitor (ACSM) for routine monitoring of the composition and mass concentrations of ambient aerosol, Aerosol. Sci. Technol., 45, 780-794, 2011b.

Paatero, P. and Tapper, U.: Positive matrix factorization - a nonnegative factor model with optimal utilization of error-estimates of data values, Environmetrics, 5, 111-126, 1994.

Pandolfi, M., Querol, X., Alastuey, A., Jimenez, J. L., Cusack, M., Reche, C., Pey, J., Mohr, C., DeCarlo, P. F., Ortega, A., Day, D., Prevot, A. S. H., Baltensperger, U., Artiñano, B., Baldasano, J. M., Jorba, O., Burkhart, J., Hansel, A., Schallhart, S., Müller, M., Metzger, M., Saarikoski, S., Cubison, M. J., Ng, S., Lorente, J., Nemitz, E., Di Marco, C., Peñuelas, J., Sicard, M., Comeron, A., Amato, F., Moreno, T., Viana, M., Pérez, N., Moreno, N., Seco, R., Filella, I., Llusià, J., Piot, M., and Pay, M. T.: Sources and origin of PM in the Western Mediterranean Basin: An overview of the DAURE campaign, in preparation, 2012.
Pérez, C., Nickovic, S., Baldasano, J. M., Sicard, M., Rocadenbosch, F., and Cachorro, V. E.: A long Saharan dust event over the western Mediterranean: Lidar, Sun photometer observations, and regional dust modeling, J. Geophys. Res., 111, D15214, doi:10.1029/2005JD006579, 2006.

Pérez, N., Pey, J., Castillo, S., Viana, M., Alastuey, A., and Querol, X.: Interpretation of the variability of levels of regional background aerosols in the Western Mediterranean, Sci. Total Environ., 407, 527-540, 2008a.

Pérez, N., Pey, J., Querol, X., Alastuey, A., López, J. M., and Viana, M.: Partitioning of major and trace components in $\mathrm{PM}_{10}-\mathrm{PM}_{2.5^{-}}$ $\mathrm{PM}_{1}$ at an urban site in Southern Europe, Atmos. Environ., 42, 1677-1691, 2008b.

Pey, J., Pérez, N., Querol, X., Alastuey, A., Cusack, M., and Reche, C.: Intense winter atmospheric pollution episodes affecting the Western Mediterranean, Sci. Total Environ., 408, 1951-1959, 2010.

Querol, X., Alastuey, A., Rodriguez, S., Plana, F., Ruiz, C. R., Cots, N., Massagué, G., and Puig, O.: $\mathrm{PM}_{10}$ and $\mathrm{PM}_{2.5}$ source apportionment in the Barcelona Metropolitan area, Catalonia, Spain, Atmos. Environ., 35, 6407-6419, 2001.

Reche, C., Viana , M., Amato, F., Querol, X., Moreno, T., Minguillón, M. C., Alastuey, A., Hillamo, R., Teinilä, K., Saarnio, K., Seco, R., and Mohr, C.: Biomass burning contributions to urban aerosols in a coastal Mediterranean city, in preparation, 2012.

Reche, C., Viana, M., Moreno, T., Querol, X., Alastuey, A., Pey, J., Pandolfi, M., Prévôt, A., Mohr, C., Richard, A., Artiñano, B., Gomez-Moreno, F. J., and Cots, N.: Peculiarities in atmospheric particle number and size-resolved speciation in an urban area in the western Mediterranean: Results from the DAURE campaign, Atmos. Environ., 45, 5282-5293, 2011.

Rogge, W. F., Hildemann, L. M., Mazurek, M. A., Cass, G. R., and Simonelt, B. R. T.: Sources of fine organic aerosol 1., Charbroilers and meat cooking operations, Environ. Sci. Technol., 25, 1112-1125, 1991.

Sandradewi, J., Prévôt, A. S. H., Szidat, S., Perron, N., Alfarra, M. R., Lanz, V. A., Weingartner, E., and Baltensperger, U.: Using aerosol light absorption measurements for the quantitative determination of wood burning and traffic emission contributions to particulate matter, Environ. Sci. Technol., 42, 3316-3323, 2008.

Schauer, J. J., Rogge, W. F., Hildemann, L. M., Mazurek, M. A., and Cass, G. R.: Source apportionment of airborne particulate matter using organic compounds as tracers, Atmos. Environ., 30, 3837-3855, 1996.

Schauer, J. J., Kleeman, M. J., Cass, G. R., and Simoneit, B. R. T.: Measurement of emissions from air pollution sources. 1., C-1 through C-29 organic compounds from meat charbroiling, Environ. Sci. Technol., 33, 1566-1577, 1999.

Schauer, J. J., Kleeman, M. J., Cass, G. R., and Simoneit, B. R. T.: Measurement of emissions from air pollution sources. 4. C1-C27 organic compounds from cooking with seed oils, Environ. Sci. Technol., 36, 567-575, 2001.

Slowik, J. G., Stainken, K., Davidovits, P., Williams, L. R., Jayne, J. T., Kolb, C. E., Worsnop, D. R., Rudich, Y., DeCarlo, P. F., and Jimenez, J. L.: Particle morphology and density characterization by combined mobility and aerodynamic diameter measurements, Part 2: Application to combustion-generated soot aerosols as a function of fuel equivalence ratio, Aerosol. Sci. Technol., 38, 
1206-1222, doi:10.1080/027868290903916, 2004.

Slowik, J. G., Vlasenko, A., McGuire, M., Evans, G. J., and Abbatt, J. P. D.: Simultaneous factor analysis of organic particle and gas mass spectra: AMS and PTR-MS measurements at an urban site, Atmos. Chem. Phys., 10, 1969-1988, doi:10.5194/acp-10-19692010, 2010.

Sueper, D.: ToF-AMS High Resolution Analysis Software - Pika, online available at: http://cires.colorado.edu/jimenez-group/ ToFAMSResources/ToFSoftware/PikaInfo/, 2008.

Sun, Y. L., Zhang, Q., Schwab, J. J., Demerjian, K. L., Chen, W. N., Bae, M. S., Hung, H. M., Hogrefe, O., Frank, B., Rattigan, O. V., and Lin, Y. C.: Characterization of the sources and processes of organic and inorganic aerosols in New York city with a high-resolution time-of-flight aerosol mass spectrometer, Atmos. Chem. Phys., 11, 1581-1602, doi:10.5194/acp-11-15812011, 2011.

Tsigaridis, K., Krol, M., Dentener, F. J., Balkanski, Y., Lathière, J., Metzger, S., Hauglustaine, D. A., and Kanakidou, M.: Change in global aerosol composition since preindustrial times, Atmos. Chem. Phys., 6, 5143-5162, doi:10.5194/acp-6-5143-2006, 2006.

Ulbrich, I. M., Canagaratna, M. R., Zhang, Q., Worsnop, D. R., and Jimenez, J. L.: Interpretation of organic components from Positive Matrix Factorization of aerosol mass spectrometric data, Atmos. Chem. Phys., 9, 2891-2918, doi:10.5194/acp-9-2891-2009, 2009.

Ulbrich, I. M., Canagaratna, M. R., Cubison, M. J., Zhang, Q., Ng, N. L., Aiken, A. C., and Jimenez, J. L.: Three-dimensional factorization of size-resolved organic aerosol mass spectra from Mexico City, Atmos. Meas. Tech., 5, 195-224, doi:10.5194/amt5-195-2012, 2012.

Watson, J. G.: Visibility: Science and regulation, J. Air Waste Manage., 52, 628-713, 2002.
Weimer, S., Alfarra, M. R., Schreiber, D., Mohr, M., Prévôt, A. S. H., and Baltensperger, U.: Organic aerosol mass spectral signatures from wood-burning emissions: Influence of burning conditions and wood type, J. Geophys. Res., 113, D10304, doi:10.1029/2007JD009309, 2008.

Wiedensohler, A., Birmili, W., Nowak, A., Sonntag, A., Weinhold, K., Merkel, M., Wehner, B., Tuch, T., Pfeifer, S., Fiebig, M., Fjäraa, A. M., Asmi, E., Sellegri, K., Depuy, R., Venzac, H., Villani, P., Laj, P., Aalto, P., Ogren, J. A., Swietlicki, E., Roldin, P., Williams, P., Quincey, P., Hglin, C., Fierz-Schmidhauser, R., Gysel, M., Weingartner, E., Riccobono, F., Santos, S., Grüning, C., Faloon, K., Beddows, D., Harrison, R. M., Monahan, C., Jennings, S. G., O’Dowd, C. D., Marinoni, A., Horn, H.-G., Keck, L., Jiang, J., Scheckman, J., McMurry, P. H., Deng, Z., Zhao, C. S., Moerman, M., Henzing, B., and de Leeuw, G.: Particle mobility size spectrometers: harmonization of technical standards and data structure to facilitate high quality long-term observations of atmospheric particle number size distributions, Atmos. Meas. Tech. Discuss., 3, 5521-5587, doi:10.5194/amtd-3-55212010, 2010.

Zhang, Q., Alfarra, M. R., Worsnop, D. R., Allan, J. D., Coe, H., Canagaratna, M. R., and Jimenez, J. L.: Deconvolutionand quantification of hydrocarbon-like and oxygenated organic aerosols based on aerosol mass spectrometry, Environ. Sci. Technol., 39, 4938-4952, 2005a.

Zhang, Q., Worsnop, D. R., Canagaratna, M. R., and Jimenez, J. L.: Hydrocarbon-like and oxygenated organic aerosols in Pittsburgh: insights into sources and processes of organic aerosols, Atmos. Chem. Phys., 5, 3289-3311, doi:10.5194/acp-5-32892005, 2005b.

Zhao, Y., Hu, M., Slanina, S., and Zhang, Y.: Chemical compositions of fine particulate organic matter emitted from Chinese cooking, Environ. Sci. Technol., 41, 99-105, 2006. 